\title{
Tüketici Yenilikçiliğinin Algılanan Risk Üzerine Etkisi: Kuşadası'ndaki 5 Yıldızlı Otel Müşterileri Örneği \\ (The Effect of Consumer Innovativeness on Perceived Risk: The Example of 5 Star Hotel's Guests in Kuşadası) ${ }^{1}$
}

\author{
Muhammed BAYKAL iD a Ahu YAZICI AYYILDIZ iD b \\ a Adnan Menderes Üniversitesi, Sosyal Bilimler Enstitüsü, Aydın, Türkiye. muhbarbay@gmail.com \\ b Adnan Menderes Üniversitesi, Turizm Fakültesi, Aydın, Türkiye. ayazici@adu.edu.tr
}

\begin{tabular}{|c|c|}
\hline MAKALE BİLGİSI & ÖZET \\
\hline Anahtar Kelimeler: & ıç - Konaklama işletmeleri açısından öneme sahip olan tüketici yenilikçiliği ve algılanan risk \\
\hline & $\begin{array}{l}\text { kavramlarının konu alındığı bu çalışmanın temel amacı; konaklama işletmelerindeki misafirlerin } \\
\text { yenilikçilik eğilimleri ve boyutlarının algılanan risk boyutları üzerinde etkisini ortaya koymaktır. }\end{array}$ \\
\hline Algilanan Risk & $\begin{array}{l}\text { Yöntem - Araştırma kapsamında verilerin toplanması için Kuşadası ilçesinde faaliyet gösteren } 5 \\
\text { yıldızlı konaklama işletmelerinde konaklayan misafirler üzerine anket çalışması yapılmıştır. }\end{array}$ \\
\hline $\begin{array}{l}\text { Gönderilme Tarihi } 29 \text { Kasım } \\
2019\end{array}$ & $\begin{array}{l}\text { Araştırmanın yapıldığı } 2019 \text { yılı Ocak-Mayıs döneminde Kuşadası'nda bulunan otellerin } \\
\text { yoğunluğunun az olması ve bazı otellerin kapalı olması nedeniyle açı bulunan } 7 \text { konaklama } \\
\text { işletmesinden toplanan anketlerin } 402 \text { tanesi araştırma kapsamına alınarak analize tabi tutulmuştur. }\end{array}$ \\
\hline Revizyon Tarihi 29 Şubat & $\begin{array}{l}\text { Araştırma kapsamında katılımcılardan elde edilen verilerin normal dağılım göstermesi nedeniyle } \\
\text { parametrik analizlerden faydalanılmıştır. }\end{array}$ \\
\hline Kabul Tarihi 5 Mart 2020 & $\begin{array}{l}\text { Bulgular - Tüketici yenilikçiliği ile algılanan risk negatif bir ilişkiye sahiptir. Bilişsel yenilikçilik } \\
\text { boyutunun toplam-zaman riski, fiziksel-performans riski, psikolojik-finansal risk boyutu ve sosyal } \\
\text { risk boyutu üzerinde etkisi yok iken, hedonik, sosyal ve fonksiyonel yenilikçilik boyutlarının etkisi } \\
\text { olduğu görülmektedir. }\end{array}$ \\
\hline $\begin{array}{l}\text { Makale Kategorisi: } \\
\text { Araştırma Makalesi }\end{array}$ & $\begin{array}{l}\text { Tartışma - Hizmete dayalı konaklama işletmelerinde konaklayan misafirler yeni bir ürün ve hizmeti } \\
\text { satın almadan önce risk algılamaktadır. Kişilik özelliklerinin kişiden kişiye farklılık göstermesi, belirli } \\
\text { bir durum karşısında algılanan riskin düzeyini de etki etmektedir. Bu nedenle konaklama işletmeleri } \\
\text { pazarda yer alan potansiyel misafirlerin kişilik özelliklerini bilerek hem pazar payını genişletebilir } \\
\text { hem de satışların artmasını sağlayabilir. }\end{array}$ \\
\hline ARTICLE INFO & ABSTRACT \\
\hline $\begin{array}{l}\text { Keywords: } \\
\text { Innovativeness }\end{array}$ & $\begin{array}{l}\text { Purpose - The aim of this study in which consumer innovativeness and perceived risk concepts which } \\
\text { are important for the hotels, is to show the effect of the guest the dimensions of innovativeness trend } \\
\text { on the perceived risk level. }\end{array}$ \\
\hline $\begin{array}{l}\text { Consumer Innovativeness } \\
\text { Perceived Risk }\end{array}$ & $\begin{array}{l}\text { Design/methodology/approach - This questionnaire was applied to the guests in 5-star hotels in } \\
\text { Kuşadas1. } 402 \text { questionnaires obtained from } 7 \text { hotels were evaluated for this study because of the } \\
\text { decrease in guest number and closed hotels in January-March term in 2019. In the result of the study it }\end{array}$ \\
\hline $\begin{array}{l}\text { Received } 29 \text { November } 2019 \\
\text { Revised } 29 \text { February } 2020 \\
\text { Accepted } 5 \text { March } 2020\end{array}$ & $\begin{array}{l}\text { has been found that the dimensions of consumer innovativeness have effects on the dimensions of } \\
\text { perceived risk. Due to the normal distribution of the data obtained from the participants within the } \\
\text { research, parametric analyzes were used. }\end{array}$ \\
\hline Article Classification: & $\begin{array}{l}\text { Findings - Consumer innovation has a negative relationship with perceived risk. Cognitive } \\
\text { innovation dimension has no effect on total-time risk, physical-performance risk, psychological- } \\
\text { financial risk dimension and social risk dimension. However, it is seen that hedonic, social and } \\
\text { functional innovation dimensions have an effect. }\end{array}$ \\
\hline Research Article & $\begin{array}{l}\text { Discussion - The guests who stay at the hotels based on service perceive risks before they purchase a } \\
\text { new product or a service. Different personal traits affect the perceived risk level against a certain } \\
\text { situation. Therefore, knowing the personal traits of potential guests, hotels both enlarge the marketing } \\
\text { rate and provide the increase in purchasing. }\end{array}$ \\
\hline
\end{tabular}

${ }^{1}$ Bu çalışma, 2019 yılında yapılmış olan “Tüketici Yenilikçiliği ve Kişilik Özelliklerinin Algılanan Risk Üzerine Etkisi: Kuşadası'ndaki 5 Yıldızlı Otel Müşterileri Örneği" isimli tezden üretilmiştir.

\section{Önerilen Atıf/ Suggested Citation}

Baykal, M., Yazıcı Ayyıldız, A. (2020). Tüketici Yenilikçiliğinin Algılanan Risk Üzerine Etkisi: Kuşadası'ndaki 5 Yıldızlı Otel Müşterileri Örneği, İşletme Araştırmaları Dergisi, 12 (1), 510-530. 


\section{GIRISŞ}

Dünyanın küreselleşmesi ve teknolojinin hızla gelişmesi tüketicilerin isteklerini ve beklentilerini büyük oranda etkilemektedir. Tüketicilerin değişen istek ve beklentilerinin karşılanması için işletmeler daha önceki ürünlerden farklı olarak yeni ürünler sunmak için çaba göstermeleri gerekmektedir. Birçok işletmede olduğu gibi konaklama işletmelerinde de tüketicilerin istek ve beklentilerini karşılayan yeni bir ürün geliştirmek, işletmeye rekabet üstünlüğü kazandırma bakımından avantaj sağlayacaktır. Bunun yanında tüketiciler tarafından yeni bir ürün veya hizmetin benimsenmemesi, işletmelerin hem zaman hem de finansal olarak kayıp yaşamasına neden olacaktır. Diğer işletmelere karşı rekabet avantajı sağlamak için tüketicilerin bu yeni ürün veya hizmetleri benimsemeleri gerekmektedir.

Tüketiciler tarafından yeni bir ürün veya hizmetin benimsenmesi birbirinden farklılık göstermektedir. Bazı tüketiciler yenilikleri daha erken benimseme meylinde bulunurken bazıları ise daha geç benimseme meylinde bulunabilmektedir. Yenilikçi tüketiciler diğer tüketicilere oranla yenilikleri daha erken benimseyen kişilerdir. Yenilikçi tüketicilerin satın aldıkları ürün veya hizmet hakkında ağızdan ağıza iletişimde bulunarak diğer tüketicilere olumlu mesajlar vermesi, yeni ürünleri diğer tüketicilere göre daha erken benimsemesi ve daha çok harcama yapması işletmelere avantaj sağlamaktadır. Ayrıca yeni bir ürün veya hizmet doğası gereği belirsizlikler içermektedir. Belirsizliğin olduğu yerde de algılanan riskten söz etmek mümkündür. Bu nedenle tüketici yenilikçiliği ile algılanan risk birbiriyle ilişkili iki kavramdır (Özoğlu ve Bülbül, 2013: 131-132).

Tüketici yenilikçliği ile ilgili daha önce yapılan araştırmalara bakıldığında; genel olarak kişilik özelliği olarak ve demografik özellikler ile ilişkisi incelenmiştir. Uluslararası araştırmalarda ise son zamanlarda tüketici yenilikçiliği ile algılanan risk ve satın alma davranışı arasındaki ilişki incelenmeye başlanmıştır. Türkiye'de de tüketici yenilikçiliği konusunda yapılan araştırmaların sınırlı olduğu görülmektedir (Bülbül ve Özoğlu, 2014: 44).

Tüketici yenilikçiliğinin algılanan risk üzerine olan muhtemel etkilerinin ne olduğunun gösterilmesi amacı taşıyan bu çalışmanın insan emeğine dayanan ve insan ilişkilerinin daha yoğun yaşandığı turizm sektörü içerisinde yer alan otel işletmelerindeki konaklayan misafirler üzerine daha önce yapılmamış olması, mevcut durumun ortaya konması açısından eksiklik olarak görülmektedir. Aynı zamanda bu araştırma sonuçları, konaklama işletmelerinin mevcut ve potansiyel misafirlerini daha iyi tanımalarına olanak sağlayarak ve misafirlerin ne tür risk algıladığına ilişkin bilgiler edinerek hem yeni bir ürün ve hizmeti pazara sunarken hem de mevcut ve potansiyel misafirlerin işletmeye sadakatini sağlarken uygun stratejiler belirlenmesi ve riskin en aza indirilmesi veya ortadan kaldırılması konusunda işletmelere yardımcı olacaktır.

\section{TÜKETİCI YENİLIKÇİLIĞ́̇}

Yenilemek anlamına gelen inovasyon kelimesi, Latince "innovare" kelimesinden türetilmiştir. Yapılan araştırmalara göre yenilikçi davranış, herhangi bir örgütsel düzeyde faydalı yeniliğin uygulanmasına, tanıtılmasına ve üretilmesine yön veren bireysel eylemler olarak tanımlanmaktadır (Joseph, 2007: 14).

Türkçe'de inovasyon kelimesinin anlam karşıllı̆̆ tam olarak yoktur. İnovasyon kelimesinin yerine kolay anlaşılması için yenilik kelimesi kullanılmaktadır. Ancak inovasyon kelimesinin özünde yaratıcılık kavramının olması nedeniyle bu konuda yenilik kavramından ayrılmaktadır. Farklı bir görüşe göre inovasyon kavramının yenilik olarak kabul edilmemesinin nedeni; kavramın özünde yer alan yeni şeylerin ekonomik ve toplumsal değişime, faydaya dönüşmesi gerekliliğidir. Bu nedenle Türkçe'de kullanılan yenilik kavramı inovasyon kavramının anlam karşılığını yeterince karşılamamaktadır (Köse, 2012: 6).

Yenilik karar süreci olarak da adlandırılan yeniliğin bir kişi tarafından benimsenmesi beş aşamadan oluşmaktadır. Bir kişi veya bir başkalarının bir yenilik ile ilgili ilk bilginin alınmasından sonra yeniliğe ilişkin bir tutum oluşturması, yeniliği benimsemesi veya reddetmesi, yenilik ile ilgili sahip olunan fikir veya düşüncelerin uygulanması ve son olarak da verilen bu kararın onaylanması sürecinden oluşan bir yenilik karar sürecidir (Köse, 2012: 64).

Tüketici yenilikçiliği, daha geniş ve genel bir kavram olan doğal yenilikçiliğin bir parçasıdır. Tüketicilerin yenilikçi davranışlarını kapsamaktadır. Yenilikçiliği, belirli bir ürün kategorisindeki bir ürünün, pazara 


\section{Baykal - A. Yazıcı Ayyıldız 12/1 (2020) 510-530}

çıışından belirli bir süre sonra, diğer tüketicilere oranla daha erken benimsenmesi ve satın alma davranışında bulunulması olarak tanımlamak mümkündür (Başar, 2012: 51).

Tüketici yenilikçiliği ile ilgili yapılan çalışmalara bakıldığında, 1960'lı yıllarda çalışmaların başladığı görülmektedir. Buna rağmen birçok araştırmacının (Rogers ve Shoemaker, 1971; Midgley ve Dowling, 1978; Hirschman, 1980) sıklıkla alıntı yaptığı çalışmalar, 1970'li yıllarda başlamaktadır (Akdoğan ve Karaaslan, 2013: 4).

Rogers ve Shoemaker, 1971 yılında yapmış oldukları çalışmada, tüketici yenilikçiliğini, "bir kişinin, sosyal sistemin ortalama üyesinden yeni fikirleri benimseme konusunda nispeten daha erken davranma derecesi" olarak tanımlamaktadır (Leicht vd., 2018: 4). Hurt ve arkadaşları ise 1977 yılında yaptıkları çalışmada, tüketici yenilikçiliğini, "kişilerin değişime gönüllü olma durumu" olarak tanımlayarak, yenilikçiliğe farklı bir yorum getirmiştir (Deniz, 2012: 58).

Midgley ve Dowling tüketici yenilikçiliğini “bir kişinin diğer kişilerin iletişim deneyimlerinden bağımsız olarak yenilik kararı alması ve yeniliklere açık olma derecesi" olarak tanımlamaktadır. İlk zamanlarda araştırmacılar, yeniliğin benimsenme zamanına odaklanmaktadırlar. Midgley ve Dowling'in yapmış oldukları tanımda yer alan "diğer kişilerin iletişim deneyimlerinden bağımsız olarak yenilik kararı alması" ifadesi, önceki tanımdan bu noktada ayrılmaktadır. Yeniliklerin bir boyutunun olmasına eleştiriler yöneltilmiş ve yeniliğin bir boyutunun olamayacağını savunmuşlardır (Akdoğan ve Karaaslan, 2013: 4; Midgley ve Dowling, 1978: 235). Hirschman'a (1980: 283-292) göre ise kişisel olarak, her tüketici bir dereceye kadar yenilikçidir. Kişiler, yaşamı boyunca algılarındaki bazı yeni nesneleri veya fikirleri benimsemektedir. Yenilikçilik bütün insanlarda var olan bir kavramdır. Her tüketici belirli bir yenilikçilik payı ile doğmakta, yaşam süresi boyunca bu değişmemekte ve kişilik özelliği olarak kalmaktadır. Yenilikçilik, yeni kullanımların ortaya çıkardığı örneklerin sayısı ve her yeni kullanımın özelliklerini belirleyen yenilik derecesi olmak üzere iki bileşene sahiptir. Midgley ve Dowling'in yapmış olduğu tanım, "bağımsız karar verme" ifadesi üzerinde dururken, Hirschman'ın yenilik ile ilgili yapmış olduğu tanım, "içsel yenilik arayışı" ifadesi üzerinde durmaktadır (Hirschman, 1980: 283-292; Eryiğit ve Kavak, 2011: 97).

Rogers (1983: 242-247), tüketici yenilikçiliğini, "bir kişinin veya başka bir benimseme biriminin, yeni fikirlerin benimsenmesi için yayılma araştırmalarının diğer kavramlarından, sistemin diğer üyelerinden daha erken davranma derecesi" olarak tanımlamaktadır. Rogers, "yeniliklerin yayılması" adlı çalışmasında, yenilikçileri, benimseme zamanına göre yenilikçilik, erken benimseyenler, erken çoğunluk, geç çoğunluk ve gecikenler olmak üzere beş ayrı kategoriye ayırmaktadır. Rogers'ın bu çalışması, birçok araştırmacı için yenilik konusunda öncülük eden bir araştırma olmuştur. Venkatraman (1991: 53) ise tüketici yenilikçiliğini, tüketicileri yeni ürünler almaya yönlendiren bir kişilik özelliği olarak tanımlamakta ve hem duyusal hem de bilişsel yenilikçiliğin, yeni ürün satın alma ile önemli pozitif ilişkilere sahip olmasını beklemektedir.

Goldsmith ve Hofacker, 1991 yılında yaptığı çalışmada, tüketici yenilikçiliğinin iki ana boyutundan biri olan, ürüne özgü yenilikçiliği geliştirmiştir ve tüketici yenilikçiliğinin bir ürün kategorisinden diğerine farklılık gösterebileceğini varsaymaktadır (Wooyang vd., 2011: 716). Midgley ve Dowling'in daha önce yapmış oldukları çalışmada geliştirdikleri "kişisel yeniliçilik" ölçeğinin yalnızca kişilik özelliklerine dayalı olduğunu ve ürün kategorisindeki yenilikçi davranış farklılıklarına yer verilmediği için "ilgi alanına özgü yenilikçilik" ölçeğini geliştirmişlerdir (Özoğlu ve Bülbül, 2013: 132).

Daghfous ve diğerleri (1999: 316-317) ise tüketici yenilikçiliği ile ilgili daha önce yapılan çalışmalardan elde edilen boyutları bir araya getirmeyi amaçlamıştır. Tüketim davranışının bilişsel, duygusal ve çabasal yönlerini yansıtan üç temel boyuttan oluşmaktadır. Bilişsel boyut, kişinin yeni bir ürün ile ilgili bilgilere sahip olması ve bu ürün ile ilgili faydaları bilgileri iletebilme kapasitesidir. Duygusal boyut, ürüne ve ürün ile ilgili bilgilere duygusal olarak ilgi duyulmasıdır. Çabasal boyut ise yeni ürünlerin sürekli kullanımı için tahmini hız, gösterilen çabadır. Bu ölçüm, kişinin yayılma sürecinin belirli bir aşamasında bir yeniliği benimseme eğilimini tahmin etmek için kullanılan sürekli ve çok boyutlu ölçümdür.

Goldsmith ve Foxall, 2003 yılında yaptıkları çalışmada, tüketici yenilikçiliğinin üç farklı yaklaşımdan oluştuğunu belirtmişlerdir. Bu yaklaşımlar; içsel yenilikçilik, ilgi alanına özgü yenilikçilik ve tüketici yenilikçiliğidir. İçsel yenilikçilik, kişinin kişisel özelliklere bağlı olarak, yeni olan bir şeyi denemek için sahip olduğu istekliliktir. İçsel yenilikçilik bir kişilik özelliğidir. İlgi alanına özgü yenilikçilik, kişinin belirli biri 


\section{Baykal - A. Yazıcı Ayyıldız 12/1 (2020) 510-530}

ürün kategorisinde ve ilgi duyduğu sektörde ön plana çıkması için sergilediği öncü davranışlardır. Tüketici yenilikçiliği ise yeni bir ürünü ilk satın alma eğilimidir (Köker ve Maden, 2017: 838). Roehrich (2004: 674) için ise yenilikçilik, uyarım ve benzersizlik ihtiyacı olmak üzere iki merkezi ihtiyacın bir ifadesidir. Roechrich'in ölçeği iki boyuttan oluşmaktadır. Hedonist yenilikçilik boyutu, uyarmaya duyulan ihtiyacı karşılarken sosyal yenilikçilik boyutu, benzersizliğe duyulan ihtiyacı karşılamaktadır.

Tellis ve arkadaşları daha önce yapılan araştırmalarda; yeni ürünlerin ortaya çıkması ve yayılmasının ülkelere göre büyük ölçüde değişiklik gösterdiğini belirtmektedir. Bununla birlikte, yeni ürünlerin ortaya çıkmasında ve yayılmasında mevcut ekonomik ve kültür ölçekleri, bütün ülkeler arasındaki değişimi açıklamamaktadır. Bu nedenle, tüketicilerin yeni ürünler benimsemesini öngörebilecek yeni ve temel bir tüketici yenilikçilik ölçeğinden faydalanmanın mümkün olduğunu savunmuşlardır. Tüketici yenilikçiliğini, "tüketicilerin yeni ürünleri benimseme eğilimi" olarak tanımlamaktadırlar. Tüketici yenilikçiliğinin bu tanımıyla birlikte tüketici yenilikçiliği, bir eylemi yapan olmaktan çıkıp eylemi yapma potansiyeline sahip olma noktasına gelmiştir (Tellis vd., 2009: 1-2; Akdoğan ve Karaaslan, 2013: 4).

Vandecasteele ve Geuens (2010) ise Goldsmith ve Hofacker'in 1991 yllında geliştirdikleri ölçeğin daha çok ürün odaklı olduğunu belirtmektedir. Ayrıca yenilikçiliğin ölçülmesi için yeterli olmadığını savunmaktadırlar. Daha önceki araştırmalardaki ölçeklerde, yenilikçiliğin satın alınmasında motivasyonların yeteri kadar kullanılmadığını ve yenilik seviyesinden çok yenilik çeşitlerine önem verilmektedir. Bu nedenle hedonik, fonksiyonel, sosyal ve bilişsel olmak üzere dört boyuttan oluşan “Güdülenmiş Tüketici Yenilikçiliği” ölçeğini geliştirmiş̧lerdir (Özoğlu ve Bülbül, 2013: 132).

Birçok araştırmacı yapmış oldukları çalışmalarda tüketici yenilikçiliği kavramına farklı boyutlar kazandırmışlardır. Tüketici yenilikçiliği ile ilgili farklı sınıflandırmalar olsa da en açıklayıcı ayrımı, 2011 yılında Bartels ve Reinder yapmıştır. Bartels ve Reinder, tüketici yenilikçiliğini üç farklı şekilde sınıflandırmaktadır. İlk sınıflandırma, kişilik özelliği olarak yenilikçilik, doğuştan yenilikçilik veya yenilikçilik eğilimi olarak adlandırılmaktadır. İkinci sınıflandırma, ilgi alanına özel yenilikçiliktir. Son sınıflandırma ise gerçekleştirilmiş davranış olarak yenilikçilik veya yenilikçi davranış olarak adlandırılmaktadır (Demireli, 2014: 322).

Kişilik özelliği olarak yenilikçiliği, yenilikleri benimseme konusunda herkesin sahip olduğu ve her bir kişide farklı derecede bulunan bir kişilik özelliği olarak tanımlanmak mümkündür. Bu tür yenilikçilik, kişinin sahip olduğu deneyimleri, uyarıcıları ve yeni bilgilerin aranması için doğuştan gelen bir eğilimi ifade etmektedir. Kişilik özelliği olarak yenilikçilik, bir kişinin doğasında bulunan yenilikçi kişiliği, yatkınlığı ve bilişselliği yansıtan, gözlemlenmesi zor, bütün insanları kapsayan bir kişilik özelliğidir (Özçiftci, 2015: 137).

Daha önceki araştırmalar (Goldsmith vd., 2003; Goldsmith ve Hofacker, 1991; Handa ve Gupta, 2009; Klink ve Athaide, 2010), tüketici yenilikçiliğinin ilgi alanına karşı genelleme yapılmasının sorunlu olabileceğini öne sürmektedirler. Goldsmith ve Hofacker tüketici yenilikçiliğini ölçmek için "belirli bir ilgi alanı içerisinde ürün yeniliklerini öğrenme ve benimseme eğilimi" olarak tanımlanan ilgi alanına özgü yenilikçilik yaklaşımını önermektedir (Chao vd., 2013: 617). Başka bir deyişle ilgi alanına özel yenilikçilik, kişinin ilgi alanı içerisinde olan yeni bir ürünü benimsemesi ve ürün hakkında bilgilerin öğrenilmesindeki yatkınlığıdır. Araştırmacılar tarafından tüketici yenilikçiliğini ölçmek için genellikle bu yaklaşım kullanılmaktadır (Menidjel vd., 2017: 634).

Ürün temel yenilikçilik olarak da adlandırılan ilgi alanına özel yenilikçilik, kişilik özelliği olarak yenilikçilik ile yenilikçi davranış arasında bir düzeye sahiptir. Kişilik özelliği olarak yenilikçliğe göre ilgi alanına özel yenilikçilik yenilikçi eğilimi daha iyi tahmin etmektedir. Goldsmith ve Hofacker'e (1991) göre yenilikçilik ilgi duyulan ürün kategorisine göre farklılık göstermektedir. Tüketinin yenilikçi eğilimi, ürüne duyulan ilginin ve bilginin derecesine göre belirlenmektedir. Tüketicinin belirli bir ürün grubu hakkında bilgiye sahip olması, yakınlık hissetmesi ve kolay kullanıma elverişli olması, ilgi alanına özel yenilikçiliğe büyük etki etmektedir (Kambar, 2016: 91).

Kişinin sahip olduğu yenilikçi eğilim, her zaman davranışa dönüşememektedir. Bu yüzden yenilikçi eğilim ile yenilikçi davranış kavramları bu konuda birbirinden ayrılmaktadır (Akdoğan ve Karaaslan, 2013: 6). Yenilikçi davranış yaklaşımı, yeni ürün ve hizmetlerin satın alınması, gerçekleştirilmiş davranış olarak yenilikçilik ve kullanım yenilikçiliği olarak da ifade edilmektedir. Yenilikçi davranış yaklaşımı, tüketiciler 


\section{Baykal - A. Yazıcı Ayyıldız 12/1 (2020) 510-530}

tarafından ürün veya hizmetlerin farklı amaçlarla kullanılması ile ilgilidir. Tüketicinin daha önce farklı bir amaçla kullandığı bir ürünü, başka bir amaçla tekrardan kullanılmasıdır. Tüketici yeni bir ürünü eski bir kullanım faaliyeti içerisinde de kullanabilmektedir. Her iki durum da yenilikçi davranış kapsamındadır (Demireli, 2014: 323).

\section{ALGILANAN RISK}

Algılanan risk kavramı ise tüketicilerin satın almak veya kullanmak istedikleri bir ürün veya hizmeti satın almadan önce karşılaşmış oldukları belirsizlik durumu ve beklenilen zararı ifade etmektedir (Karamustafa ve Erbaş, 2011: 109). İlk olarak Bauer tarafından 1960 yılında, risk almanın bir tüketici davranışı örneği olduğu öne sürülmüştür. Bauer, tüketicinin herhangi bir eyleminin tam olarak tahmin edilmesinin güç olduğunu ve olumsuz sonuçlar doğurabileceğini öne sürmüştür. Tüketici davranışı bu açıdan risk taşımaktadır. Bauer, yalnızca nesnel riskle değil aynı zamanda öznel risk (algılanan risk) ile ilgilenmiştir. Bauer'e göre algılanan risk, tüketicilerin yalnızca karar öncesi bilgi edinme ve işleme faaliyetleriyle ilişkili değildir, aynı zamanda karar verme sonrası süreçlerle de ilgilidir (Ross, 1975: 1).

Algılanan risk kavramının öznel bir özelliğe sahip olmasından dolayı alternatiflerin sonuçları ve gerçekleşme olasılığını kesin olarak bilinmesini engellemekte ve belirsizlik katmaktadır. Aynı zamanda tüketicilerin sahip oldukları özellikler, sonuçların ve olasılıkların algılanması konusunda değişiklik gösterebilmektedir (Ateşoğlu ve Türker, 2014: 12). Yapılan araştırmalara bakıldığında da genel olarak "belirsizlik" ve "sonuçlar" araştırmaların ölçüm prosedürü olarak kullanıldığı görülmektedir. Birçok araştırmacı riskin varlığı için bu iki boyutun bir arada kullanılması gerektiğini savunmaktadır (Karabulut, 2013: 5518).

Mitchell'e (1998: 177) göre algılanan riski etkileyen faktörler; kişisel, ürüne ilişkin ve durumsal olmak üzere üç faktörden oluşmaktadır. Kişisel faktörler; yaş, cinsiyet ekonomik sınıf, ülke içi farklılıklar ve psikolojik tehditlerden oluşurken, ürüne ilişkin faktörler; dağıtım kanalı, jenerik ve markalı ürünler, ürün kullanım zamanı, ürün/hizmet karması ve ülke orijininden oluşmaktadır. Durumsal faktörler ise grup tartışmaları ve ürün ilgileniminden oluşmaktadır.

Algılanan risk ile ilgili literatürde birçok çalışma yapılmıştır. Literatürde ilk yapılan çalışma ise Roselious tarafından 1971 yılında yapılmıştır. Roselious' a göre tüketicilerin genel olarak maruz kaldığı birbirinden farklı kayıp türü vardır. Bu kayıp türleri; zaman kaybı, fiziksel kayıp, ego kaybı ve para kaybıdır. 1972 yılında ise Jacoby ve Kaplan, Roselious'un (1971) belirlemiş olduğu boyutlara karşılık beş farklı risk boyutu önermiştir. Jacoby ve Kaplan' a göre algılanan risk boyutları; finansal, performans, sosyal, fiziksel ve psikolojik risktir. Algılanan risk boyutları genel olarak Jacoby ve Kaplan (1972) tarafından belirlenmiş olsa da altıncı risk boyutu olarak zaman riskini tanımlayan Roselious (1971) olmuştur. Belirlenen altı risk boyutu genel olarak algılanan riskin önemli bir bölümünü açıkladığını göstermektedir (Akturan, 2007: 56; Keleş, 2011: 18).

Finansal risk, aşırı yüksek fiyattaki ürün veya hizmet için ödenen para için en iyi değeri alamama olasılığını göstermektedir. Genel olarak, satın alınan ürün veya hizmetin kendisine ödenen paraya değmemesi riski vardır (Boksberger vd., 2007: 92). Performans riski, satın alınan ürün veya hizmetin tüketici tarafından değerlendirilmesi sonucu istenilen performansı vermemesi ve uygun bir şekilde çalışmaması veya çalışma olasılığının düşük olması olarak tanımlanmaktadır (Ateşoğlu ve Türker, 2014: 13). Sosyal risk, tüketici tarafından satın alınan bir ürün veya hizmetin aptalca ve güvenilmez olarak görünmesi ve tüketicinin çevresine karşı potansiyel statü kaybı yaşaması durumu olarak tanımlanmaktadır (Featherman ve Pavlou, 2003: 455). Fiziksel risk, tüketici tarafından satın alınan ürün ve hizmetin uygun şekilde veya başarısız olarak kullanılmasıyla birlikte tüketicinin sağlı̆̆ı veya güvenliğinin tehlikeye girmesi durumu olarak tanımlanmaktadır (Temeloğlu, 2016: 101). Psikolojik risk, tüketici tarafından satın alınan ürün veya hizmetin kendi imajına zarar vermesi veya tüketicinin kişiliğine kötü yansıması olasılığı olarak tanımlanmaktadır (Carroll, 2009: 61). Zaman riski, tüketici tarafından satın alınan ürün veya hizmette yaşanan olumsuz nedenlerden dolayı tüketicinin satın almış olduğu ürün veya hizmeti onarmak veya değiştirmek istemesi sonucunda yaşanan zaman kaybı olarak tanımlanmaktadır (Roselius, 1971: 58).

Tüketicinin bir ürün veya hizmeti satın almasında en önemli unsurlardan biri risktir. Özellikle yeni bir ürün satın alınmak istendiğinde tüketicinin algıladığı risk daha fazla olabilmektedir. Çünkü yeni ürün veya 
hizmetin belirsizlik özelliği taşıması tüketicinin risk algılamasına sebep olmaktadır. Her bir tüketicinin yenilikçilik düzeyi de farklılık gösterebilmektedir. Tüketicinin sosyal, fonksiyonel, hedonik ve bilişsel yenilikçilik düzeylerinin her biri farklı olduğu gibi algıladıkları risk düzeyi de farklılık gösterebilmektedir. Bazı tüketiciler yeni bir ürün veya hizmetin satın almadan önce performans bakımında risk algılamakta, bazıları ise finansal, sosyal, fiziksel ve psikolojik bakımdan risk algılamaktadır. Özellikler işletmeler ve markalar açısından tüketicinin nasıl etkilendiğinin bilinmesi, tüketiciyi anlamak ve uygun pazarlama stratejileri geliştirmek açısından önemlidir.

\section{YÖNTEM}

\subsection{Araştırmanın Amacı}

Bu çalışmanın temel amacı, Kuşadası'nda faaliyet gösteren 5 yıldızlı konaklama işletmelerindeki misafirlerin yenilikçi eğilim boyutlarının algılanan risk boyutları üzerine etkisini ortaya koymaktır.

\subsection{Araştırmanın Modeli}

Araştırmanın türü açklayıcı araştırmadır. Tüketici yenilikçiliğinin algılanan risk üzerine etkisinin sonuçlarının ortaya koyulması için oluşturulan araştırma modeli Şekil 1'de gösterilmektedir. Bu bağlamda sosyal yenilikçilik, fonksiyonel yenilikçilik, hedonik yenilikçilik ve bilişsel yenilikçilik gibi tüketici yenilikçiliğine bağlı boyutların ve performans riski, finansal risk, sosyal risk, fiziksel risk, psikolojik risk ve zaman riski gibi algılanan riske bağlı boyutların araştırma modeline dâhil edilmesine karar verilmiştir.

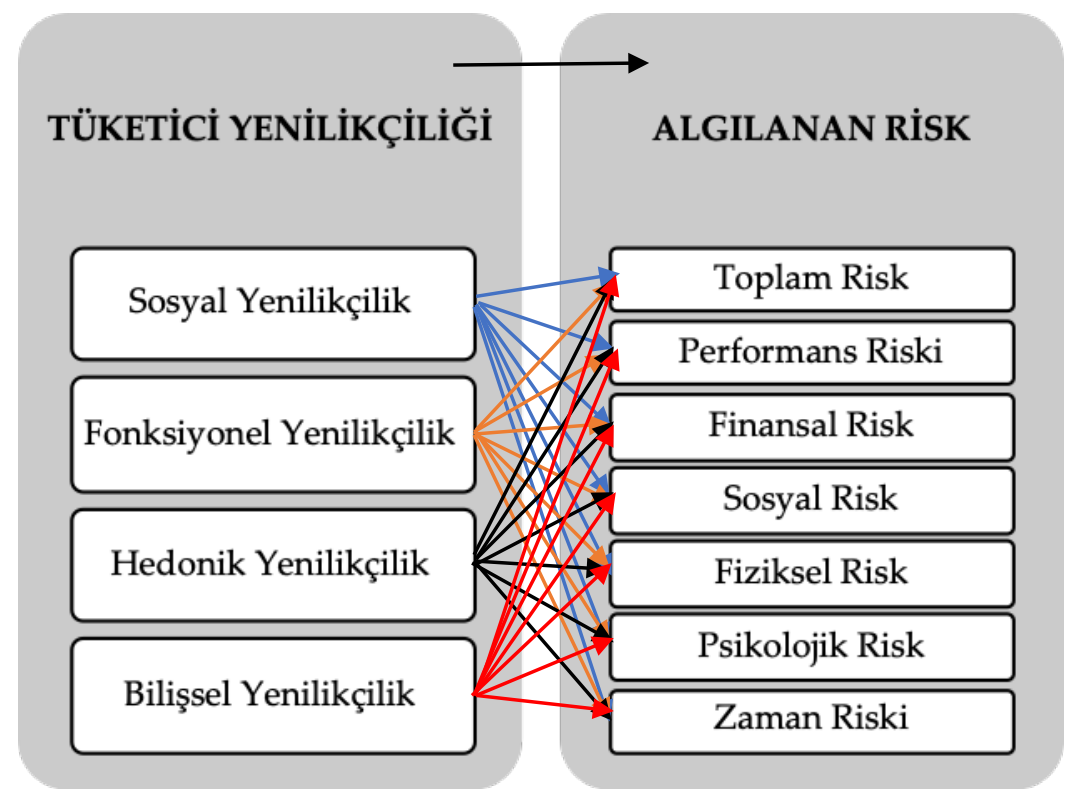

Şekil 1. Araştırma Modeli (Ölçek boyutlarından derlenerek hazırlanmıştır)

Araştırmanın temel hipotezleri ve alt hipotezler aşağıda gösterilmektedir:

\section{H1: Tüketici yenilikçiliği ve algılanan risk arasında anlamlı bir ilişki vardır.}

\section{$\mathrm{H}_{2}$ : Tüketici yenilikçiliğinin algılanan risk üzerine etkisi vardır.}

$\mathbf{H}_{2 a}$ : Tüketici yenilikçiliği boyutlarının toplam-zaman risk üzerine etkisi vardır.

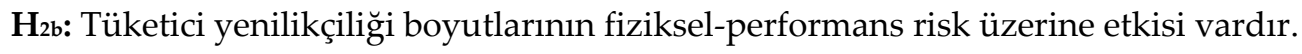

$\mathbf{H}_{2 c \text { : }}$ Tüketici yenilikçiliği boyutlarının psikolojik-finansal risk üzerine etkisi vardır.

$\mathbf{H}_{2 \mathrm{~d}}$ : Tüketici yenilikçiliği boyutlarının sosyal risk üzerine etkisi vardır.

\subsection{Evren ve Örneklem}

Türk turizminde ayrıcalıklı bir konuma ve konaklama işletmeleri açısından zengin bir envantere sahip olan Kuşadası ilçesinin evreni temsil edebilecek örnekleme sahip olduğu varsayılmıştır. Bu nedenle hizmete dayalı sunumların konaklama işletmeleri açısından oldukça önemli olduğu, yerli ve yabancı misafirler tarafından yeteri kadar ziyaret edildiği göz önüne bulundurulduğunda, güvenirliği fazla sonuçların elde 
edilmesi için çalışmanın evreninin Kuşadası'ndaki beş yıldızlı konaklama işletmelerinde konaklayan yerli ve yabancı misafirlerin olmasına karar verilmiştir. Aydın İl Turizm Müdürlüğü'nün (2018) verilerine bakıldığında Kuşadası'nda faaliyet gösteren işletme belgeli 10 adet 5 yıldızlı otel ve 2 adet 5 yıldız standardına sahip birinci sınıf tatil köyü bulunmaktadır. Araştırmanın yapıldığı 15 Ocak-15 Mayıs tarihleri arasında Kuşadası'nda bulunan otellerin yoğunluğunun az olması ve bazı otellerin kapalı olması nedeniyle açık bulunan 6 adet beş yıldızlı otel ve 1 adet birinci sınıf tatil köyünün bulunduğu toplam 7 adet konaklama işletmesinde konaklayan misafirler araştırmanın evrenini oluşturmuştur.

Araştırmada ana kütlenin homojen olmaması ve elde edilecek verilerin daha hızlı, daha kolay ve daha ekonomik bir şekilde toplanması için kolayda örnekleme yöntemine başvurulması gerekmektedir (Haşıloğlu vd., 2015: 20). Bu nedenle araştırmaya katılanların belirlenmesi için tesadüfi olmayan örnekleme yöntemlerinden kolayda örnekleme yöntemine başvurulmuştur. Örneklem oluşturulurken \%95 güven aralığı ve \%5 hata payı ile 384 kişiye ulaşılması amaçlanmış ve araştırma için örneklem sayısının yeterli olacağı düşünülerek toplam 700 anket dağıtılmıştır. Hem düşük sezonda olunması hem de bazı misafirlerin anket çalışmasına katılmak istememesi nedeniyle toplam 583 adet anket geri alınabilmiştir. Yapılan incelemeler sonucu toplam 181 adet anket sağlıklı veriler elde edilmesi için analize tabi tutulmayarak araştırma kapsamından çıkarılmıştır. Geriye kalan toplam 402 adet anket araştırma kapsamına alınarak analize tabi tutulmuştur.

\subsection{Veri Toplama Araci}

Araştırmada birincil ve ikincil kaynaklar taranarak yararlanılmıştır. Bu kaynaklar ışığında nicel veri toplama tekniklerinden anket yöntemi ile veri elde edilmiştir. Veri toplama işleminde uygulanan anket ölçeği üç bölümden oluşmaktadır. Anketin ilk bölümü, cinsiyet, yaş, medeni durum, gelir durumu, eğitim durumu, meslek ve son bir yıl içerisinde konaklama sayısı gibi otel misafirlerinin demografik özelliklerini tanımlamaya yöneliktir. Anketin ikinci bölümünde tüketici yenilikçiliğinin ölçülmesi için Vandecasteele ve Geuens'in (2010) geliştirmiş olduğu güdülenmiş tüketici yenilikçiliği ölçeğinin Özoğlu ve Bülbül (2013) tarafından geçerlilik ve güvenirlik çalışmasının yapıldığı ölçekten faydalanılmıştır. Bu ölçeğin seçilmesinin nedeni; diğer ölçeklere göre çok boyutlu olması ve tüketici ile ürün ilişkisini daha iyi hesaplayabilmedir. Tüketici yenilikçiliği; sosyal, fonksiyonel, hedonik ve bilişsel olmak üzere toplam 4 boyut ve 20 ifadeden oluşmaktadır. Anketin üçüncü bölümünde ise algılanan riskin ölçülmesi için Stone ve Grønhaug'un (1993) geliştirmiş olduğu ve Küpeli'nin (2014) tez çalışmasında otelcilik sektörüne uyarladığı algılanan risk ölçeğinden faydalanılmıştır. Bu ölçeğin seçilmesinin nedeni de literatürde sıklıkla diğer araştırmacılar tarafından kullanılması ve otel misafirleri üzerine uygulanabilir olmasıdır. Algılanan risk ölçeği; performans, finansal, sosyal, fiziksel, psikolojik ve zaman riski ve toplam risk olmak üzere toplam 7 boyut ve 21 ifadeden oluşmaktadır. Elde edilen verilerin analizinde ise; istatistik paket programı kullanılacaktır.

Tüketici yenilikçiliği ve algılanan risk ölçeğine ait olan ifadelere otel misafirlerinin katılım derecelerini belirtmek için 5'li Likert Ölçeği kullanılmıştır. Bu ifadeler "Kesinlikle Katılmıyorum (1)", "Katıllıyorum (2)”, “Ne Katıllyorum Ne Katılmıyorum (3)", “Katıllyorum (4)", “Kesinlikle Katıllyorum (5)" olarak ölçeklendirilmiştir.

\subsection{Verilerin Analizi}

Anket formları Türkçe ve İngilizce olmak üzere iki farklı dilde aynı alanda çalışan akademisyenler ve İngilizce alanında uzman olan kişilerin görüşleri alınarak hazırlanmıştır. Genel olarak uygulama yapılmadan önce 5 yıldızlı bir otelde 50 kişilik bir pilot çalışma yapılmıştır. Yapılan çalışma sonucunda ankette yer alan ifadelerde herhangi bir değişiklik yapılmamış ve anketin son haliyle kullanılması gerektiği kanaatine varılmıştır.

Araştırma kapsamında katılımcılardan elde edilen verilerin normal dağılım göstermesi nedeniyle parametrik analizlerden faydalanılmıştır. Demografik özelliklere ilişkin veriler için frekans analizi, ölçeklerin yapısal geçerliliği için faktör analizi, tüketici yenilikçiliği ve algılanan risk arasındaki ilişkiyi tespit etmek için korelasyon analizi, tüketici yenilikçiliği boyutlarının algılanan risk üzerine etkisinin olup olmadığını tespit etmek için çoklu regresyon analizi kullanılmıştır. 


\subsection{Normallik Analizi}

Tüketici yenilikçiliği ve algılanan risk hakkında yapılan araştırma sonucunda elde edilen verilerin normal dağılım gösterip göstermediği incelenmiştir.

Tablo 1. Normallik analizi

\begin{tabular}{|c|c|c|}
\hline Normallik Analizi & Tüketici Yenilikçiliği Ölçeği & Algilanan Risk Ölçeği \\
\hline $\mathbf{N}$ & 402 & 402 \\
\hline Mean & 3.6905 & 2.2257 \\
\hline Median & 3.7857 & 2.0952 \\
\hline Skewness & -.729 & .683 \\
\hline Kurtosis & .442 & -.163 \\
\hline
\end{tabular}

Tablo 1'de verilen ortalama ve medyan değerlerine bakıldığında; Tüketici Yenilikçiliği (mean: 3,6905; median: 3.7857) ve Algılanan Risk (mean: 2,2257; median: 2,0952) ölçekleri değerlerinin birbirine yakın olduğu gözlenmektedir. Her iki ölçek için çarpıklık (skewness) ve basıklık (kurtosis) değerlerine bakıldığında; Tüketici Yenilikçiliği'nin çarpıklık değeri -,729 iken basıklık değeri ,442 ve Algılanan Risk'in çarpıklık değeri ,683 iken basıklık değeri ise -,163'dir. Bu değerler, çarpıklık ve basıklığın $-1,5$ ve $+1,5$ aralığında olduğunu göstermektedir. Ayrıca Waternaux'a göre örneklem sayısı 200 olan araştırmalarda kullanılan ölçekler normal dağılım göstermeyebilir. Bu ölçeklerin normal dağılım göstermiş gibi kabul edilmesi gerekmektedir (Tabachnik ve Fidell, 2013: 80). Bu doğrultuda elde edilen veriler normal dağılım göstermektedir. Bu nedenle çalışmada parametrik testlerin kullanılmasına karar verilmiştir.

\subsection{Güvenirlik Analizi}

Araştırmanın güvenirliği, bir ölçeğin ölçüm sonuçlarının farklı ana kütlelerde veya aynı ana kütleye ait farklı ana kütlelerde aynı sonucu vermesi durumudur (Şencan, 2005: 11). Bir araştırmada güvenirliği ölçmek için en çok kullanılan istatistik ise Cronbach's Alpha katsayısıdır. Cronbach's Alpha katsayısı, ölçekte yer alan bütün maddeler arasındaki ortalama korelasyonu göstermektedir. Bu değer 0 ile 1 arasında bir değerden oluşmaktadır. Değerin yüksek olması, yüksek güvenirliği göstermektedir (Pallant, 2016: 18). Şencan (2005: 128) güvenirlik katsayısının 0 ile 0.5 arasında olmasını "kabul edilemez", 0.5 ile 0.6 arasında olmasını "zayıf", 0.6 ile 0.7 arasında olmasını "kuşkulu" ve 0.7 ile 0.8 arasında olmasını ise "kabul edilebilir", 0.8 ile 0.9 arasında olmasını "iyi" ve 0.9 ve üzeri olmasını ise "yüksek" olarak ifade etmiştir.

Tablo 2. Güvenirlik Analizi

\begin{tabular}{|l|l|l|}
\hline Ölçekler & Cronbach's Alpha & Madde Sayısı \\
\hline Tüketici Yenilikçiliği &, 941 & 20 \\
\hline Algılanan Risk &, 951 & 21 \\
\hline
\end{tabular}

$\mathrm{Bu}$ araştırmada da her üç ölçeğin genel güvenirliğini ölçmek için Cronbach's Alpha istatistiğinden faydalanılmıştır. Tablo 2'de yer alan veriler incelendiğinde; tüketici yenilikçiliği ölçeğinin Cronbach's Alpha katsayısı, 0,941 olduğu görülmektedir. Bu değer tüketici yenilikçiliği ölçeğinin yüksek güvenirliğe sahip olduğunu göstermektedir. Algılanan risk ölçeğinin Cronbach's Alpha katsayısı ise 0,951 olarak bulunmuştur. Bu değer algılanan risk ölçeğinin yüksek güvenirliğe sahip olduğunu göstermektedir.

\section{BULGULAR}

\subsection{Demografik Özelliklere İlişkin Bulgular ve Değerlendirmeler}

Araştırmaya katılım sağlayan misafirlerin cinsiyet, yaş, medeni durum, gelir durumu, eğitim durumu, meslek ve son bir yılda konaklama sayısı gibi demografik özelliklerine ilişkin verileri Tablo 3'te yer almaktadır. Elde edilen verilerin incelenmesi için frekans analizinden faydalanılmıştır. 
M. Baykal - A. Yazıcı Ayyıldız 12/1 (2020) 510-530

Tablo 3. Katılımcıların Demografik Özellikleri

\begin{tabular}{|c|c|c|c|c|c|c|c|}
\hline & & $\mathbf{N}$ & $\%$ & & & $\mathbf{N}$ & $\%$ \\
\hline \multirow[b]{2}{*}{ CINSSIYET } & Kadın & 207 & 51,5 & \multirow{6}{*}{$\begin{array}{l}\text { EĞİTIM } \\
\text { DURUMU }\end{array}$} & İlkokul & 21 & 5,2 \\
\hline & Erkek & 195 & 48,5 & & Lise & 94 & 23,4 \\
\hline \multirow{5}{*}{ YAŞ } & $18-29$ & 169 & 42 & & \begin{tabular}{|l|l} 
Ön Lisans \\
\end{tabular} & 97 & 24,1 \\
\hline & $30-39$ & 87 & 21,6 & & Lisans & 151 & 37,6 \\
\hline & $40-49$ & 75 & 18,7 & & Lisansüstü & 39 & 9,7 \\
\hline & $50-59$ & 33 & 8,2 & & & & \\
\hline & 60 ve üzeri & 38 & 9,5 & \multirow{7}{*}{ MESLEK } & İşçi & 125 & 31,1 \\
\hline \multirow{2}{*}{$\begin{array}{l}\text { MEDENİ } \\
\text { DURUM }\end{array}$} & Evli & 173 & 43 & & İşveren & 44 & 10,9 \\
\hline & Bekâr & 229 & 57 & & Yönetici & 59 & 14,7 \\
\hline \multirow{7}{*}{$\begin{array}{l}\text { GELİR } \\
\text { DURUMU }\end{array}$} & 1000 TL'den az & 48 & 11,9 & & \begin{tabular}{|l|} 
Emekli \\
\end{tabular} & 45 & 11,2 \\
\hline & $1001-1500 \mathrm{TL}$ & 32 & 8 & & Öğrenci & 93 & 23,2 \\
\hline & $1501-2000 \mathrm{TL}$ & 54 & 13,4 & & Diğer & 36 & 9,9 \\
\hline & $2001-2500 \mathrm{TL}$ & 94 & 23,4 & & & & \\
\hline & $2501-3000 \mathrm{TL}$ & 67 & 16,7 & \multirow{5}{*}{$\begin{array}{l}\text { SON BİR YILDA } \\
\text { KONAKLAMA } \\
\text { SAYISI }\end{array}$} & $1 \mathrm{kez}$ & 170 & 42,3 \\
\hline & 3001-3500 TL & 44 & 10,9 & & $2 \mathrm{kez}$ & 100 & 24,9 \\
\hline & 3501 ve üzeri TL & 63 & 15,7 & & $3 \mathrm{kez}$ & 61 & 15,2 \\
\hline \multirow[t]{2}{*}{ MİLLIYYET } & Yerli & 259 & 64,4 & & $4 \mathrm{kez}$ ve üzeri & 71 & 17,6 \\
\hline & Yabanc1 & 143 & 35,6 & & & & \\
\hline
\end{tabular}

Tablo 3'te yer alan bilgilere bakıldığında hem kadın hem de erkek katılımcıların sayısı birbirine yakın ve katılımcıların çoğunun genç, bekâr, gelir seviyesi 2001-3000 TL aralığında, lisans mezunu, işçi, daha çok yerli ve yılda en az 1 kez otellerde konaklayanlar olduğu görülmektedir. Bülbül ve Özoğlu'nun (2014) yapmış oldukları çalışmada, kadınlar erkeklere oranla daha fazla katılım sağlamıştır. Katılımcıların yaşına bakıldığında ise bu çalışmada olduğu gibi çoğunluğun 18-21 yaş aralığında olduğu görülmektedir. Koç vd.'nin (2017) Instagram kullanan toplam 300 kişiye yapmış olduğu çalışmada ise katılımcıların çoğunun genç ve lise mezunu olduğu görülmektedir. Hirunyawipada ve Paswan'ın (2006) ise öğrenciler üzerine yapmış oldukları çalışmada hem kadın hem de erkek katılımcı sayısının birbirine yakın olduğu, katılımcıların çoğunun 21-30 yaş aralığında ve düşük gelirli kişiler olduğu görülmektedir. Bu çalışmalarda katılımcıların demografik özellikleri birbiriyle benzerlik gösterirken, Lee ve Huddleston'ın (2006) yapmış olduğu çalışmadaki katılımcıların demografik özelliklerine bakıldığında ise katılımcıların büyük çoğunluğunu kadınlar ve bekârlar oluşturmaktadır. Ancak katılımcıların çoğu 20-23 yaş aralığında olan gençlerden oluşmaktadır. Bu da araştırmadaki katılımcıların yaşları ile benzerlik göstermektedir. 


\subsection{Tüketici Yenilikçiliğine İlişkin Betimleyici İstatistikler}

Tüketici yenilikçiliği ölçeğine ilişkin tanımlayıcı istatistikler Tablo 4'te yer almaktadır.

Tablo 4. Tüketici Yenilikçiliği Ölçeğine İlişkin Tanımlayıcı İstatistikler

\begin{tabular}{|c|c|c|c|}
\hline Boyut & İfadeler & Ortalama & $\begin{array}{l}\text { Standart } \\
\text { Sapma }\end{array}$ \\
\hline \multirow{5}{*}{$\begin{array}{l}\text { Sosyal } \\
\text { Yenilikçilik }\end{array}$} & Başkalarını etkileyecek yenilikleri satın almayı severim & 3.450 & 1.33017 \\
\hline & $\begin{array}{l}\text { Başkalarından beni ayıracak yeni bir ürüne sahip } \\
\text { olmayı isterim }\end{array}$ & 3.465 & 1.31556 \\
\hline & $\begin{array}{l}\text { Kendimi arkadaş ve komşularıma gösterebileceğim yeni } \\
\text { ürünleri denemek isterim }\end{array}$ & 3.375 & 1.32149 \\
\hline & $\begin{array}{l}\text { Arkadaşlarımın sahip olmadıkları yeni ürünleri alarak } \\
\text { onların önünde olmayı isterim. }\end{array}$ & 2.972 & 1.42186 \\
\hline & $\begin{array}{l}\text { Başkaları tarafından görülebilen ve saygınlığımı } \\
\text { artıracak yenilikleri kesinlikle satın }\end{array}$ & 3.335 & 1.39974 \\
\hline \multirow{5}{*}{$\begin{array}{l}\text { Fonksiyonel } \\
\text { Yenilikçilik }\end{array}$} & $\begin{array}{l}\text { Zaman tasarrufu sağlayacak yeni bir ürün piyasaya } \\
\text { çıkarsa, hemen satın alırım }\end{array}$ & 3.673 & 1.18343 \\
\hline & $\begin{array}{l}\text { Daha fazla konfor sağlayan yeni bir ürünü satın almak } \\
\text { konusunda tereddüt etmem }\end{array}$ & 3.781 & 1.13517 \\
\hline & $\begin{array}{l}\text { Daha fazla fonksiyonelliğe sahip yeni bir ürünü satın } \\
\text { alma konusunda tereddüt etmem. }\end{array}$ & 3.753 & 1.08922 \\
\hline & $\begin{array}{l}\text { Daha kullanışlı yeni bir ürün bulursam onu satın almayı } \\
\text { tercih ederim }\end{array}$ & 3.855 & 1.04706 \\
\hline & $\begin{array}{l}\text { İşimi daha da kolaylaştıracak yeni bir ürünü almak } \\
\text { benim için bir zorunluluktur. }\end{array}$ & 3.549 & 1.17061 \\
\hline \multirow{5}{*}{$\begin{array}{l}\text { Hedonik } \\
\text { Yenilikçilik }\end{array}$} & Yenilikleri kullanmak bana haz verir & 3.771 & 1.07447 \\
\hline & Yeni ürünler almak kendimi iyi hissettirir & 3.815 & 1.10810 \\
\hline & Yenilikler hayatımı heyecanlı ve canlı kılar & 3.810 & 1.10500 \\
\hline & Bir yeniliğe sahip olmak beni mutlu eder. & 3.900 & 1.04275 \\
\hline & Yeniliklerin keşfi beni neşelendirir/keyiflendirir & 3.907 & 1.05307 \\
\hline \multirow{5}{*}{$\begin{array}{c}\text { Bilişsel } \\
\text { Yenilikçilik }\end{array}$} & $\begin{array}{l}\text { Çoğunlukla sorunumu çözmeye yardım eden yenilikleri } \\
\text { satın alırım }\end{array}$ & 3.920 & 1.05765 \\
\hline & $\begin{array}{l}\text { Bilgilerimi geliştirecek yenilikleri bulur ve bu yenilikleri } \\
\text { hemen satın alırım }\end{array}$ & 3.798 & 1.10166 \\
\hline & $\begin{array}{l}\text { Beni mantıksal olarak düşünmeye sevk eden yeni } \\
\text { ürünleri sıklıkla satın alırım }\end{array}$ & 3.748 & 1.09365 \\
\hline & $\begin{array}{l}\text { Yeteneklerimi geliştirecek yeni ürünleri sıklıkla satın } \\
\text { alırım }\end{array}$ & 3.865 & 1.07887 \\
\hline & $\begin{array}{l}\text { Zihnimi çalıştıran yeni ürünleri satın alan bir } \\
\text { insanımdır. }\end{array}$ & 3.898 & 1.05322 \\
\hline
\end{tabular}

Tablo 4'e bakıldığında misafirlerin en yüksek tüketici yenilikçiliği ortalamalarının bilişsel yenilikçilik boyutunda toplandığı görülmektedir. Otelde konaklayan misafirlerin vermiş oldukları cevaplar doğrultusunda "Çoğunlukla sorunumu çözmeye yardım eden yenilikleri satın alırım." ifadesinin 3.920 ile en yüksek ortalamaya sahip olduğu görülmektedir. Misafirlerin en düşük tüketici yenilikçiliği ortalamalarının ise sosyal yenilikçilik boyutunda toplandığı görülmektedir. Tüketici yenilikçiliği ölçeğine ilişkin en düşük ortalamaya sahip ifadenin ise 2.972 ile "Arkadaşlarımın sahip olmadıkları yeni ürünleri alarak onların önünde olmayı isterim." olduğu görülmektedir. Tüketici yenilikçiliği ölçeğine ilişkin ortalamalara bakıldığında; otel misafirlerinin yenilikçi eğilimlerinin orta düzeyde olduğu görülmektedir.

\subsection{Algilanan Riske İlişkin Betimleyici İstatistikler}

Algılanan risk ölçeğine ilişkin tanımlayıcı istatistikler Tablo 5’te yer almaktadır. 
M. Baykal - A. Yazıcı Ayyıldız 12/1 (2020) 510-530

Tablo 5. Algılanan Risk Ölçeğine İlişkin Tanımlayıcı İstatistikler

\begin{tabular}{|c|c|c|c|}
\hline Boyut & İfadeler & Ortalama & $\begin{array}{c}\text { Standart } \\
\text { Sapma }\end{array}$ \\
\hline \multirow{3}{*}{ Toplam Risk } & $\begin{array}{l}\text { Bu otelin hizmetlerini almış olmak genel olarak benim için bir } \\
\text { kayıptır. }\end{array}$ & 2.054 & 1.04129 \\
\hline & $\begin{array}{l}\text { Bu otelin hizmetlerini almış olmak hata yaptığımı } \\
\text { düşündürür. }\end{array}$ & 2.022 & 1.06864 \\
\hline & Otel hizmetlerini almak için birtakım problemler yaşadım. & 2.186 & 1.10655 \\
\hline \multirow{3}{*}{ Sosyal Risk } & $\begin{array}{l}\text { Bu otelden hizmet aldığım için arkadaşlarım arasında itibarım } \\
\text { artar. }\end{array}$ & 2.577 & 1.20317 \\
\hline & Bazı arkadaşlarımın gösteriş yaptığımı düşünebilir. & 2.547 & 1.20056 \\
\hline & Değer verdiğim kişiler akılsızca davrandığımı düşünebilir. & 2.276 & 1.15867 \\
\hline \multirow{3}{*}{ Zaman Riski } & Otel hizmetlerinin kullanım şeklini öğrenmek çok zaman alır. & 2.200 & 1.11495 \\
\hline & $\begin{array}{l}\text { Bilgi araştırma ve satın alma süreçleri çok fazla vakit kaybına } \\
\text { neden olur. }\end{array}$ & 2.306 & 1.11946 \\
\hline & $\begin{array}{l}\text { Hizmet süreleri çok uzun olması nedeniyle vakit kaybıdır. } \\
\text { (giriş, çıkış, yemek servisi gibi) }\end{array}$ & 2.204 & 1.16965 \\
\hline \multirow[b]{3}{*}{ Finansal Risk } & Bu otelden hizmet alarak paramı boşa harcadım. & 2.067 & 1.16746 \\
\hline & Bu otel hizmetlerine para ödemek akıllıca değildir. & 2.022 & 1.12420 \\
\hline & Otel hizmetleri ödediğim paranın karşıllı̆ını vermez. & 2.069 & 1.10547 \\
\hline \multirow{3}{*}{ Fiziksel Risk } & Otel hizmetlerinin güvenli olmadığından endişelenirim. & 2.159 & 1.14073 \\
\hline & $\begin{array}{l}\text { Otel hizmetlerinin fizyolojik rahatsızlıklara (baş ağrısı, } \\
\text { gerginlik, uyku bozukluğu gibi) neden olmasından } \\
\text { endişelenirim. }\end{array}$ & 2.183 & 1.21304 \\
\hline & Oteldeki potansiyel fiziksel riskler konusunda endişelenirim. & 2.330 & 1.17857 \\
\hline \multirow{3}{*}{$\begin{array}{l}\text { Performans } \\
\quad \text { Riski }\end{array}$} & $\begin{array}{l}\text { Beklediğim hizmet performansını sunamayacağı konusunda } \\
\text { endişelenirim. }\end{array}$ & 2.482 & 1.22360 \\
\hline & $\begin{array}{l}\text { Beklediğim faydanın sağlanmayacağı konusunda } \\
\text { endişelenirim. }\end{array}$ & 2.419 & 1.20791 \\
\hline & $\begin{array}{l}\text { Hizmetlerin ne kadar güvenli ve emniyetli olduğu konusunda } \\
\text { endişelenirim. }\end{array}$ & 2.412 & 1.20623 \\
\hline \multirow[t]{3}{*}{$\begin{array}{c}\text { Psikolojik } \\
\text { Risk }\end{array}$} & $\begin{array}{l}\text { Bu otelden hizmet alırken psikolojik olarak rahatsızlık } \\
\text { duyarım. }\end{array}$ & 2.126 & 1.20528 \\
\hline & Bu otelden hizmet alırken huzursuz hissederim. & 2.052 & 1.15098 \\
\hline & Bu otelden hizmet alırken gergin hissederim. & 1.995 & 1.15541 \\
\hline
\end{tabular}

Tablo 5'e bakıldığında misafirlerin en yüksek algılanan risk ortalamalarının sosyal risk boyutunda toplandığı görülmektedir. Otelde konaklayan misafirlerin vermiş oldukları cevaplar doğrultusunda "Bu otelden hizmet aldığım için arkadaşlarım arasında itibarım artar." ifadesinin 2.577 ile en yüksek ortalamaya sahip olduğu görülmektedir. Misafirlerin en düşük algılanan risk ortalamalarının ise finansal risk boyutunda toplandığı görülmektedir. Algılanan risk ölçeğine ilişkin en düşük ortalamaya sahip ifadenin ise 1.995 ile "Bu otelden hizmet alırken gergin hissederim." olduğu görülmektedir. Algılanan risk ölçeğine ilişkin ortalamalara bakıldığında; otel misafirlerinin risk düzeylerinin düşük olduğu görülmektedir.

\subsection{Tüketici Yenilikçiliği Ölçeği Faktör Analizi}

Tüketici yenilikçiliği ölçeğinin 20 ifadesi, elde edilen veriler üzerinde temel bileşenler analizine tabi tutulmadan önce faktör analizi için uygun olup olmadığına bakılmıştır. Tabachnick ve Fidell (2013: 618) örneklem büyüklügünün en az 300 olmasının faktör analizi için rahatlatıcı olacağını ifade etmektedir. Araştırmanın örneklem büyüklüğünün 300'den fazla olması faktör analizi için uygun olduğunu göstermektedir. Verilerin faktör analizine uygun olup olmadığına bakmak için kullanılan diğer ölçümler ise Bartlett testi (Bartlett, 1954) ve Kaiser-Meyer-Olkin (Kaiser 1970, 1974) örneklem yeterliliği ölçümüdür. Bartlett testinin anlamlı olması $(p<.05)$ ve KMO değerinin 0.6 ve bu değerden büyük olması ölçeğin faktör analizi için uygun olduğunu göstermektedir (Pallant, 2016: 201). Tablo 6'ya bakıldığında Bartlett testinin 
$(\mathrm{p}<.001)$ anlamlı olduğu ve KMO değerinin (.924) .6'dan büyük olduğu görülmektedir. Bu nedenle tüketici yenilikçiliği ölçeğinin faktör analizi için uygun olduğu görülmüştür.

Tablo 6. Tüketici Yenilikçiliği Ölçeği Kaiser-Meyer-Olkin Ölçümü ve Bartlett Testi

\begin{tabular}{|l|l|}
\hline Kaiser-Meyer-Olkin (KMO) & .924 \\
\hline Bartlett Testi (Sig.) & .000 \\
\hline
\end{tabular}

Faktör analizinde diğer bir konu ise faktör değerlerinin 0.50'nin altında olmaması gerektiğidir (Hair vd., 2014: 102). Bu nedenle faktör yük değeri 0.50'nin altında kalan 10. İfade faktör analizinden çıkarılmıştır. Geriye kalan 19 ifadenin güvenirliği için yapılan güvenirlik analizi sonucunda Cronbach Alpha değerinin 0.940 olduğu görülmüştür. Bu değer ölçeğin güvenilir olduğunu göstermektedir.

Tablo 7. Tüketici Yenilikçiliği Ölçeği Faktör Analizi Özet Sonuçları

\begin{tabular}{|c|c|c|c|c|}
\hline Faktör ve İfadeler & \begin{tabular}{|c|} 
Faktör \\
Yükleri
\end{tabular} & Özdeğer & \begin{tabular}{|c|} 
Açılklanan \\
Varyans
\end{tabular} & $\begin{array}{l}\text { Cronbach } \\
\text { Alpha }\end{array}$ \\
\hline Faktör 1: Hedonik Yenilikçilik & & 3,968 & 20,886 & ,914 \\
\hline Bir yeniliğe sahip olmak beni mutlu eder. & 825 & & & \\
\hline Yenilikler hayatımı heyecanlı ve canlı kılar. & ,818 & & & \\
\hline Yeni ürünler almak kendimi iyi hissettirir. & 787 & & & \\
\hline Yenilikleri kullanmak bana haz verir. & ,715 & & & \\
\hline Yeniliklerin keşfi beni neşelendirir/keyiflendirir. & ,707 & & & \\
\hline Faktör 2: Sosyal Yenilikçilik & & 3,958 & 20,831 & 927 \\
\hline $\begin{array}{l}\text { Kendimi arkadaş ve komşularıma gösterebileceğim yeni } \\
\text { ürünleri denemek isterim. }\end{array}$ & 877 & & & \\
\hline Başkalarını etkileyecek yenilikleri satın almayı severim & 837 & & & \\
\hline $\begin{array}{l}\text { Arkadaşlarımın sahip olmadıkları yeni ürünleri alarak onların } \\
\text { önünde olmayı isterim. }\end{array}$ & 821 & & & \\
\hline $\begin{array}{l}\text { Başkaları tarafından görülebilen ve saygınlığımı artıracak } \\
\text { yenilikleri kesinlikle satın alırım. }\end{array}$ & 814 & & & \\
\hline $\begin{array}{l}\text { Başkalarından beni ayıracak yeni bir ürüne sahip olmayı } \\
\text { isterim. }\end{array}$ & ,795 & & & \\
\hline Faktör 3: Bilişsel Yenilikçilik & & 3,677 & 19,353 & 910 \\
\hline Yeteneklerimi geliştirecek yeni ürünleri sıklıkla satın alırım. & ,834 & & & \\
\hline Zihnimi çalıştıran yeni ürünleri satın alan bir insanımdır. & 834 & & & \\
\hline $\begin{array}{l}\text { Beni mantıksal olarak düşünmeye sevk eden yeni ürünleri } \\
\text { sıklıkla satın alırım. }\end{array}$ & 810 & & & \\
\hline $\begin{array}{l}\text { Bilgilerimi geliştirecek yenilikleri bulur ve bu yenilikleri } \\
\text { hemen satın alırım. }\end{array}$ & ,783 & & & \\
\hline $\begin{array}{l}\text { Çoğunlukla sorunumu çözmeye yardım eden yenilikleri satın } \\
\text { alırım. }\end{array}$ & ,587 & & & \\
\hline Faktör 4: Fonksiyonel Yenilikçilik & & 2,641 & 13,901 & ,843 \\
\hline $\begin{array}{l}\text { Daha fazla konfor sağlayan yeni bir ürünü satın almak } \\
\text { konusunda tereddüt etmem }\end{array}$ & ,823 & & & \\
\hline $\begin{array}{l}\text { Daha fazla fonksiyonelliğe sahip yeni bir ürünü satın alma } \\
\text { konusunda tereddüt etmem. }\end{array}$ & 787 & & & \\
\hline $\begin{array}{l}\text { Zaman tasarrufu sağlayacak yeni bir ürün piyasaya çıkarsa, } \\
\text { hemen satın alırım }\end{array}$ & 680 & & & \\
\hline $\begin{array}{l}\text { Daha kullanışlı yeni bir ürün bulursam onu satın almayı tercih } \\
\text { ederim. }\end{array}$ & ,567 & & & \\
\hline
\end{tabular}


Tablo 7 incelendiğinde ifadelerin ortak faktör varyansının 0.591 ve üzerinde, faktör yüklerinin ise 0.567 ve üzerinde olduğu görülmektedir. Varimax rotasyonu analizi sonucunda varyansın sirasiyla \%20.886, \%20.831, \%19.353 ve \%13.901'ini açıklayan 1'üstünde öz değere sahip dört bileşenin olduğu görülmektedir. $\mathrm{Bu}$ dört bileşen toplam varyansın \%74'ünü açıklamaktadır. Faktör analizinde en önemli kriterlerden biri, açılanan varyansın toplam varyansın üzerinden \%50'den fazla olması gerektiğidir (Yaşlığlu, 2017: 77). Toplam varyansın 19 ifadenin yer aldığı dört bileşenin açıklanan varyansı açılayabilme gücüne sahip olduğunu göstermektedir. Faktör analizi sonucunda; 1. Faktör altında hedonik yenilikçilik boyutunun toplam 5 ifadeden, 2. Faktör altında sosyal yenilikçilik boyutunun 5 ifadeden, 3 . Faktör altında bilişsel yenilikçilik boyutunun 5 ifadeden ve 4 . Faktör altında fonksiyonel yenilikçilik boyutunun 4 ifadeden oluştuğu görülmektedir. Cronbach Alpha ile yapılan güvenirlik analizleri sonucunda toplam 4 faktörün güvenirlik katsayılarına sırasıyla bakıldığında hedonik yenilikçiliğin .914, sosyal yenilikçiliğin 0.927 , bilişsel yenilikçiliğin .910 ve fonksiyonel yenilikçiliğin .843 olduğu görülmektedir. Bu değerler tüketici yenilikçiliği ölçeği boyutlarının güvenilir olduğunu göstermektedir.

Bu doğrultuda tüketici yenilikçiliği ölçeği; hedonik yenilikçilik (5 ifade), sosyal yenilikçilik (5 ifade), bilişsel yenilikçilik ( 5 ifade) ve fonksiyonel yenilikçilik (4 ifade) boyutlarından oluşmaktadır. Ölçekten yalnızca 10. ifade çıkarılmış ve geriye toplam 19 ifade kalmıştır.

\subsection{Algılanan Risk Ölçeği Faktör Analizi}

Algılanan risk ölçeğinin 21 ifadesi, elde edilen veriler üzerinde temel bileşenler analizine tabi tutulmadan önce faktör analizi için uygun olup olmadığına bakılmıştır. Tabachnick ve Fidell (2013: 618) örneklem büyüklüğünün en az 300 olmasının faktör analizi için rahatlatıcı olacağını ifade etmektedir. Araştırmanın örneklem büyüklügünün $300^{\prime}$ den fazla olması faktör analizi için uygun olduğunu göstermektedir. Korelasyon matrisine bakıldığında 0.232 ve 0.276 katsayıları dışındaki ifadelerin korelasyon katsayılarının 0.317 ile 0.777 arasında değiştiği görülmektedir. Verilerin faktör analizine uygun olup olmadığına bakmak için kullanılan diğer ölçümler ise Bartlett testi (Bartlett, 1954) ve Kaiser-Meyer-Olkin (Kaiser 1970, 1974) örneklem yeterliliği ölçümüdür. Bartlett testinin anlamlı olması $(\mathrm{p}<.05)$ ve KMO değerinin 0.6 ve bu değerden büyük olması ölçeğin faktör analizi için uygun olduğunu göstermektedir (Pallant, 2016: 201). Tablo 8'e bakıldığında Bartlett testinin ( $\mathrm{p}<.000)$ anlamlı olduğu ve KMO değerinin (.927) .6'dan büyük olduğu görülmektedir. Bu nedenle algılanan risk ölçeğinin faktör analizi için uygun olduğu görülmüştür.

Tablo 8. Algılanan Risk Ölçeği Kaiser-Meyer-Olkin Ölçümü ve Bartlett Testi

\begin{tabular}{|l|l|}
\hline Kaiser-Meyer-Olkin (KMO) & .927 \\
\hline Bartlett Testi (Sig.) & .000 \\
\hline
\end{tabular}

Faktör analizinde diğer bir konu ise faktör değerlerinin 0.50'nin altında olmaması gerektiğidir (Hair vd., 2014: 102). Bu nedenle faktör yük değeri 0.50 'nin altında kalan ve çapraz yüklenen 1., 2. ve 13. İfadeleri faktör analizinden çıkarılmıştır. Geriye kalan 18 ifadenin güvenirliği için yapılan güvenirlik analizi sonucunda Cronbach Alpha değerinin 0.942 olduğu görülmüştür. Bu değer ölçeğin güvenilir olduğunu göstermektedir.

Tablo 9. Algılanan Risk Ölçeği Faktör Analizi Özet Sonuçları

\begin{tabular}{|c|c|c|c|c|}
\hline Faktör ve İfadeler & $\begin{array}{l}\text { Faktör } \\
\text { Yükleri }\end{array}$ & Özdeğer & $\begin{array}{l}\text { Açılklanan } \\
\text { Varyans }\end{array}$ & $\begin{array}{l}\text { Cronbach } \\
\text { Alpha }\end{array}$ \\
\hline Faktör 1: Toplam-Zaman Riski & & 3,849 & 21,834 & 890 \\
\hline $\begin{array}{lcccc}\begin{array}{l}\text { Otel hizmetlerini } \\
\text { problemler yaşadım. }\end{array} & \text { almak için birtakım } \\
\end{array}$ & ,507 & & & \\
\hline $\begin{array}{l}\text { Otel hizmetlerinin kullanım şeklini öğrenmek } \\
\text { çok zaman alır. }\end{array}$ & ,786 & & & \\
\hline $\begin{array}{l}\text { Bilgi araştırma ve satın alma süreçleri çok fazla } \\
\text { vakit kaybına neden olur. }\end{array}$ & 788 & & & \\
\hline $\begin{array}{l}\text { Hizmet süreleri çok uzun olması nedeniyle } \\
\text { vakit kaybıdır. (giriş, çıkış, yemek servisi gibi) }\end{array}$ & 825 & & & \\
\hline $\begin{array}{l}\text { Bu otelden hizmet alarak paramı boşa } \\
\text { harcadım. }\end{array}$ & 687 & & & \\
\hline
\end{tabular}




\begin{tabular}{|c|c|c|c|c|}
\hline Faktör 2: Fiziksel-Performans Riski & & 3,834 & 21,303 & ,922 \\
\hline $\begin{array}{l}\text { Otel hizmetlerinin fizyolojik rahatsızlıklara (baş } \\
\text { ağrısı, gerginlik, uyku bozukluğu gibi) neden } \\
\text { olmasından endişelenirim. }\end{array}$ & ,527 & & & \\
\hline $\begin{array}{l}\text { Oteldeki potansiyel fiziksel riskler konusunda } \\
\text { endişelenirim. }\end{array}$ & ,786 & & & \\
\hline $\begin{array}{l}\text { Beklediğim hizmet } \\
\text { sunamayacağı konusunda endişelenirim. }\end{array}$ & 861 & & & \\
\hline $\begin{array}{l}\text { Beklediğim faydanın } \\
\text { konusunda endişelenirim }\end{array}$ & 852 & & & \\
\hline $\begin{array}{l}\text { Hizmetlerin ne kadar güvenli ve emniyetli } \\
\text { olduğu konusunda endişelenirim. }\end{array}$ & 801 & & & \\
\hline Faktör 3: Psikolojik-Finansal Risk & & 3,689 & 20,496 & ,913 \\
\hline $\begin{array}{l}\text { Bu otel hizmetlerine para ödemek akillıca } \\
\text { değildir. }\end{array}$ & 601 & & & \\
\hline $\begin{array}{l}\text { Otel hizmetleri ödediğim paranın karşılığını } \\
\text { vermez. }\end{array}$ &, 596 & & & \\
\hline $\begin{array}{l}\text { Bu otelden hizmet alırken psikolojik olarak } \\
\text { rahatsızlık duyarım. }\end{array}$ & ,791 & & & \\
\hline Bu otelden hizmet alırken huzursuz hissederim. & 840 & & & \\
\hline Bu otelden hizmet alırken gergin hissederim. & 827 & & & \\
\hline Faktör 4: Sosyal Risk & & 2,149 & 11,941 & 771 \\
\hline $\begin{array}{l}\text { Bu otelden hizmet aldığım için arkadaşlarım } \\
\text { arasında itibarım artar. }\end{array}$ & 842 & & & \\
\hline $\begin{array}{l}\text { Bazı arkadaşlarımın } \text { gösteriş yaptığımı } \\
\text { düşünebilir. }\end{array}$ & 883 & & & \\
\hline $\begin{array}{l}\text { Değer verdiğim kişiler akılsızca davrandığımı } \\
\text { düşünebilir. }\end{array}$ & 614 & & & \\
\hline
\end{tabular}

Tablo 9 incelendiğinde ifadelerin ortak faktör varyansının 0.519 ve üzerinde, faktör yüklerinin ise 0.507 ve üzerinde olduğu görülmektedir. Varimax rotasyonu analizi sonucunda varyansın sırasıyla \%21.8, \%21.3, \%20.4 ve \%11.9'unu açıklayan 1'üstünde öz değere sahip dört bileşenin olduğu görülmektedir. Bu dört bileşen toplam varyansın \%75'ini açıklamaktadır. Faktör analizinde en önemli kriterlerden biri, açıklanan varyansın toplam varyansın üzerinden \%50'den fazla olması gerektiğidir (Yaşlığlu, 2017: 77). Toplam varyansın \%50'den fazla olması, 18 ifadenin yer aldığı dört bileşenin açıklanan varyansı açıklayabilme gücüne sahip olduğunu göstermektedir. Faktör analizi sonucunda; 1. Faktör altında toplam-zaman riski boyutunun toplam 5 ifadeden, 2. Faktör altında fiziksel-performans riski boyutunun 5 ifadeden, 3. Faktör altında psikolojik-finansal risk boyutunun 5 ifadeden ve 4 . Faktör altında sosyal risk boyutunun 3 ifadeden oluştuğu görülmektedir. Cronbach Alpha ile yapılan güvenirlik analizleri sonucunda toplam 4 faktörün güvenirlik katsayılarına sırasıyla bakıldığında toplam-zaman risk boyutunun .890, fiziksel-performans risk boyutunun .922, psikolojik-finansal risk boyutunun .913 ve sosyal risk boyutunun .771 olduğu görülmektedir. Bu değerler algılanan risk ölçeği boyutlarının güvenilir olduğunu göstermektedir.

Bu doğrultuda algılanan risk ölçeği; toplam-zaman riski (5 ifade), fiziksel-performans riski (5 ifade), psikolojik- finansal risk (5 ifade) ve sosyal risk (3 ifade) boyutlarından oluşmaktadır. Ölçekten 1.,2. ve 13. ifadeler çıkarılmış ve geriye toplam 18 ifade kalmıştır.

\subsection{Tüketici Yenilikçiliği ve Algılanan Risk İlişkisi}

$\mathrm{Bu}$ bölümde tüketici yenilikçiliği ve algılanan risk ölçekleri boyutlarının birbiriyle olan ilişkisine yer verilmektedir. Ölçeklerin boyutları arasındaki ilişki gücünü ve yönünü belirlemek için Pearson momentlerçarpımı korelasyon katsayısı kullanılmıştır. Kurulan hipotezler şunlardır:

\section{H1: Tüketici yenilikçiliği ve algılanan risk arasında anlamlı bir ilişki vardır.}


Cohen'e (1988: 79-81) göre korelasyon katsayısı (r) değeri .10 ile .29 arasında değişiyorsa ilişki gücü az, .30 ile .49 arasında değişiyorsa ilişki gücü orta ve .50 ile 1.00 arasında değişiyorsa ilişki gücü büyüktür.

Tablo 10 'da yer alan sonuçlara göre hedonik, bilişsel ve fonksiyonel yenilikçilik boyutları ile algılanan risk boyutları arasında negatif bir ilişki var iken, sosyal yenilikçilik boyutu ile algılanan risk boyutlarının bir ilişkiye sahip olmadığı görülmektedir. Tüketici yenilikçiliği ve algılanan risk ölçekleri boyutlarının birbiriyle olan ilişkisini gösteren analiz sonuçlarına bakıldığında; genel olarak tüketici yenilikçiliği ile algılanan risk $(\mathrm{r}=-.152$, $\mathrm{p}=.002)$ negatif az derecede bir ilişkiye sahip olduğu görülmektedir. Bu durumda $\mathrm{H}_{1}$ hipotezi kabul edilmiştir

Tablo 10. Tüketici Yenilikçiliği ve Algılanan Risk İlişkisi

\begin{tabular}{|c|c|c|c|c|c|c|c|c|}
\hline \multirow[t]{2}{*}{ BOYUTLAR } & \multicolumn{2}{|c|}{$\begin{array}{c}\text { Toplam-Zaman } \\
\text { Riski }\end{array}$} & \multicolumn{2}{|c|}{$\begin{array}{c}\text { Fiziksel- } \\
\text { Performans Riski }\end{array}$} & \multicolumn{2}{|c|}{ Sosyal Risk } & \multicolumn{2}{|c|}{$\begin{array}{c}\text { Psikolojik-Finansal } \\
\text { Risk }\end{array}$} \\
\hline & $\mathbf{R}$ & p & $\mathbf{R}$ & 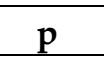 & $\mathbf{R}$ & $\mathbf{P}$ & $\mathbf{r}$ & $\mathbf{P}$ \\
\hline $\begin{array}{c}\text { Hedonik } \\
\text { Yenilikçilik } \\
\end{array}$ & -,195 & ,000 &,- 160 & ,001 &,- 022 & 655 &,- 222 & ,000 \\
\hline $\begin{array}{c}\text { Sosyal } \\
\text { Yenilikçilik }\end{array}$ &,- 046 & ,357 & ,005 & ,915 & ,022 & 667 & ,061 & ,226 \\
\hline $\begin{array}{c}\text { Bilişsel } \\
\text { Yenilikçilik } \\
\end{array}$ & -170 & ,001 &,- 103 & ,038 &,- 023 & 642 &,- 135 & ,007 \\
\hline $\begin{array}{c}\text { Fonksiyonel } \\
\text { yenilikçilik }\end{array}$ &,- 249 & ,000 &,- 150 & ,003 &,- 090 & ,071 &,- 185 & ,000 \\
\hline \multicolumn{9}{|c|}{ Tüketici Yenilikçiliği-Algılanan Risk (Genel): r=-.152, p=.002 } \\
\hline
\end{tabular}

\subsection{Tüketici Yenilikçiliği Boyutlarının Algılanan Risk Üzerine Etkisi}

Tüketici yenilikçiliği boyutlarının algılanan risk üzerine etkisine ilişkin çoklu regresyon analiz sonuçları bu bölümde yer almaktadır.

$\mathbf{H}_{2 a}$ : Tüketici yenilikçiliği boyutlarının toplam-zaman risk üzerine etkisi vardır.

Tablo 11. Tüketici Yenilikçiliği Boyutlarının Toplam-Zaman Riski Üzerine Etkisi

\begin{tabular}{|c|c|c|c|c|c|c|}
\hline \multirow{2}{*}{ Boyutlar } & \multirow{2}{*}{ B } & \multirow{2}{*}{$\mathbf{t}$} & \multirow{2}{*}{$\mathbf{p}$} & \multicolumn{2}{|c|}{$\begin{array}{c}\text { Çoklu Doğrusal } \\
\text { Bağlantı }\end{array}$} & \multirow{2}{*}{$\begin{array}{c}\text { Regresyon } \\
\text { Modeline } \\
\text { İlişkin } \\
\text { Değerler }\end{array}$} \\
\hline & & & & Tolerans & VIF & \\
\hline Hedonik Yenilikçilik &,- 108 & $-1,539$ & ,125 & 469 & 2,133 & Adj. $\mathbf{R}^{2}=, 072$ \\
\hline Sosyal Yenilikçilik & 156 & 2,624 & ,009 & 653 & 1,531 & $\mathrm{~F}=8,735$ \\
\hline Bilişsel Yenilikçilik &,- 010 &,- 146 & ,884 & ,511 & 1,957 & $\mathrm{p}=, 000$ \\
\hline Fonksiyonel Yenilikçilik &,- 262 & $-3,878$ & ,000 &, 506 & 1,977 & \\
\hline \multicolumn{7}{|c|}{ Bağımlı Değişken: Toplam-Zaman Risk } \\
\hline
\end{tabular}

Tablo 11'de hedonik yenilikçilik, sosyal yenilikçilik, bilişsel yenilikçilik ve fonksiyonel yenilikçilik boyutlarının toplam-zaman risk bağımlı değişkenine etkisini tespit etmek için yapılan çoklu regresyon analizi sonucuna göre regresyon modelinin anlamlı olduğu görülmektedir ( $F=8.735, p<.01)$. Tüketici yenilikçiliği boyutlarının toplam-zaman riski boyutunu açılama oranı $\left(R^{2}\right), 072$ düzeyindedir. Buna göre tüketici yenilikçiliğine ilişkin boyutlar toplam varyansın \%7'sini açıklamaktadır. Tüketici yenilikçiliği boyutlarının toplam-zaman riski üzerindeki göreli önem sırası fonksiyonel yenilikçilik, sosyal yenilikçilik, hedonik yenilikçilik ve bilişsel yenilikçiliktir ( $\beta$ değerleri). Bilişsel yenilikçilik ve hedonik yenilikçilik boyutunun toplam-zaman riski boyutu üzerinde etkisi yok iken, sosyal ve fonksiyonel yenilikçilik boyutlarının toplam-zaman riski boyutu üzerinde etkisi olduğu görülmektedir. 
Çoklu doğrusal bağlantı sorununun olup olmadığını tespit etmek için tolerans ve VIF değerlerine bakılabilir. Tolerans değerinin .10'un üzerinde ve VIF değerinin de 10 'dan küçük veya eşit olması çoklu doğrusal bağlantı probleminin olmadığını göstermektedir (Pallant, 2016: 176). Tablo 11'de yer alan tolerans ve VIF değerlerine bakıldığında çoklu doğrusal bağlantı sorunun olmadığı görülmektedir. $\mathrm{Bu}$ durumda $\mathrm{H}_{2 a}$ hipotezi kabul edilmiştir.

$\mathbf{H}_{2 b}$ : Tüketici yenilikçiliği boyutlarının fiziksel-performans risk üzerine etkisi vardır.

Tablo 12. Tüketici Yenilikçiliği Boyutlarının Fiziksel-Performans Riski Üzerine Etkisi

\begin{tabular}{|c|c|c|c|c|c|c|}
\hline \multirow{2}{*}{ Boyutlar } & \multirow{2}{*}{$\mathbf{B}$} & $\mathbf{t}$ & $\mathbf{p}$ & \multicolumn{2}{c|}{$\begin{array}{c}\text { Çoklu Doğrusal } \\
\text { Bağlantı }\end{array}$} & $\begin{array}{c}\text { Regresyon } \\
\text { Modeline } \\
\text { illişkin Değerler }\end{array}$ \\
\cline { 5 - 7 } & & & & Tolerans & VIF & Adj. $\mathbf{R}^{2}=, 038$ \\
\hline Hedonik Yenilikçilik &,- 169 & $-2,359$ &, $\mathbf{0 1 9}$ &, 469 & 2,133 & $\mathbf{F}=4,970$ \\
\hline Sosyal Yenilikçilik &, 162 & 2,669 &, $\mathbf{0 0 8}$ &, 653 & 1,531 & $\mathbf{p}=\mathbf{0 0 1}$ \\
\hline Bilişsel Yenilikçilik &, 029 &, 426 &, 670 &, 511 & 1,957 & \\
\hline Fonksiyonel Yenilikçilik &,- 152 & $-2,210$ &, $\mathbf{0 2 8}$ &, 506 & 1,977 & \\
\hline \multicolumn{7}{|c|}{ Bağıml Değişken: Fiziksel-Performans Risk } \\
\hline
\end{tabular}

Tablo 12'de hedonik yenilikçilik, sosyal yenilikçilik, bilişsel yenilikçilik ve fonksiyonel yenilikçilik boyutlarının fiziksel-performans risk bağımlı değişkenine etkisini tespit etmek için yapılan çoklu regresyon analizi sonucuna göre regresyon modelinin anlamlı olduğu görülmektedir ( $F=4,970 \mathrm{p}<.01)$. Tüketici yenilikçiliği boyutlarının fiziksel-performans riski boyutunu açıklama oranı $\left(R^{2}\right), 038$ düzeyindedir ve çok az bir etkiye sahiptir. Buna göre tüketici yenilikçiliğine ilişkin boyutlar toplam varyansın \%4'ünü açıklamaktadır. Tüketici yenilikçiliği boyutlarının fiziksel-performans riski üzerindeki göreli önem sırası hedonik yenilikçilik, sosyal yenilikçilik, fonksiyonel yenilikçilik ve bilişsel yenilikçiliktir ( $\beta$ değerleri). Bilişsel yenilikçilik boyutunun fiziksel-performans riski boyutu üzerinde etkisi yok iken, hedonik, sosyal ve fonksiyonel yenilikçilik boyutlarının fiziksel-performans riski boyutu üzerinde etkisi olduğu görülmektedir.

Çoklu doğrusal bağlantı sorununun olup olmadığını tespit etmek için tolerans ve VIF değerlerine bakılabilir. Tolerans değerinin .10'un üzerinde ve VIF değerinin de 10'dan küçük veya eşit olması çoklu doğrusal bağlantı probleminin olmadığını göstermektedir (Pallant, 2016: 176). Tablo 12'de yer alan tolerans ve VIF değerlerine bakıldığında çoklu doğrusal bağlantı sorunun olmadığı görülmektedir. $\mathrm{Bu}$ durumda $\mathrm{H}_{2 b}$ hipotezi kabul edilmiştir.

$\mathbf{H}_{2 \text { c: }}$ Tüketici yenilikçiliği boyutlarının psikolojik-finansal risk üzerine etkisi vardır.

Tablo 13'te hedonik yenilikçilik, sosyal yenilikçilik, bilişsel yenilikçilik ve fonksiyonel yenilikçilik boyutlarının psikolojik-finansal risk bağımlı değişkenine etkisini tespit etmek için yapılan çoklu regresyon analizi sonucuna göre regresyon modelinin anlamlı olduğu görülmektedir ( $F=12.254, p<.01)$. Tüketici yenilikçiliği boyutlarının psikolojik-finansal risk boyutunu açıklama oranı $\left(R^{2}\right), 101$ düzeyindedir. Buna göre tüketici yenilikçiliğine ilişkin boyutlar toplam varyansın \%10'unu açılamaktadır. Tüketici yenilikçiliği boyutlarının psikolojik-finansal risk üzerindeki göreli önem sırası sosyal yenilikçilik, hedonik yenilikçilik, fonksiyonel yenilikçilik ve bilişsel yenilikçiliktir ( $\beta$ değerleri). Bilişsel yenilikçilik boyutunun psikolojikfinansal risk boyutu üzerinde etkisi yok iken, hedonik, sosyal ve fonksiyonel yenilikçilik boyutlarının psikolojik-finansal risk boyutu üzerinde etkisi olduğu görülmektedir.

Tablo 13. Tüketici Yenilikçiliği Boyutlarının Psikolojik-Finansal Risk Üzerine Etkisi

\begin{tabular}{|c|c|c|c|c|c|c|}
\hline \multirow[t]{2}{*}{ Boyutlar } & \multirow[t]{2}{*}{ B } & \multirow[t]{2}{*}{$\mathrm{T}$} & \multirow{2}{*}{$\mathbf{p}$} & \multicolumn{2}{|c|}{$\begin{array}{c}\text { Çoklu Doğrusal } \\
\text { Bağlantı }\end{array}$} & \multirow{2}{*}{$\begin{array}{c}\text { Regresyon } \\
\text { Modeline } \\
\text { İlişkin Değerler }\end{array}$} \\
\hline & & & & Tolerans & VIF & \\
\hline Hedonik Yenilikçilik &,- 273 & $-3,950$ & , 000 & 469 & 2,133 & Adj. $R^{2}=, 101$ \\
\hline Sosyal Yenilikcilik & 292 & 4,983 & 000 & 653 & 1,531 & $F=12,254$ \\
\hline Bilişsel Yenilikçilik & 040 & ,598 &, 550 &, 511 & 1,957 & $\mathrm{p}=, 000$ \\
\hline Fonksiyonel Yenilikçilik &,- 201 & $-3,017$ & ,003 &, 506 & 1,977 & \\
\hline \multicolumn{7}{|c|}{ Bağımlı Değişken: Psikolojik-Finansal Risk } \\
\hline
\end{tabular}


Çoklu doğrusal bağlantı sorununun olup olmadığını tespit etmek için tolerans ve VIF değerlerine bakılabilir. Tolerans değerinin .10'un üzerinde ve VIF değerinin de 10 'dan küçük veya eşit olması çoklu doğrusal bağlantı probleminin olmadığını göstermektedir (Pallant, 2016: 176). Tablo 13'te yer alan tolerans ve VIF değerlerine bakıldığında çoklu doğrusal bağlantı sorunun olmadığı görülmektedir. Bu durumda $\mathrm{H}_{2 c}$ hipotezi kabul edilmiştir.

$\mathbf{H}_{2 \mathrm{~d}}$ : Tüketici yenilikçiliği boyutlarının sosyal risk üzerine etkisi vardır.

Tablo 14. Tüketici Yenilikçiliği Boyutlarının Sosyal Risk Üzerine Etkisi

\begin{tabular}{|c|c|c|c|c|c|c|}
\hline \multirow{2}{*}{ Boyutlar } & \multirow{2}{*}{ B } & \multirow{2}{*}{$\mathrm{T}$} & \multirow{2}{*}{$\mathbf{p}$} & \multicolumn{2}{|c|}{$\begin{array}{c}\text { Çoklu Doğrusal } \\
\text { Bağlantı }\end{array}$} & \multirow{2}{*}{$\begin{array}{c}\text { Regresyon } \\
\text { Modeline } \\
\text { İlişkin } \\
\text { Değerler }\end{array}$} \\
\hline & & & & Tolerans & VIF & \\
\hline Hedonik Yenilikçilik &, 014 & ,193 & ,847 & 469 & 2,133 & Adj. $R^{2}=, 006$ \\
\hline Sosyal Yenilikçilik & ,094 & 1,524 & ,128 & 653 & 1,531 & $F=1,613$ \\
\hline Bilişsel Yenilikçilik &, 025 & ,364 & ,716 & ,511 & 1,957 & $\mathrm{p}=, 170$ \\
\hline Fonksiyonel Yenilikçilik &,- 165 & $-2,356$ & ,019 & ,506 & 1,977 & \\
\hline
\end{tabular}

Tablo 14'te hedonik yenilikçilik, sosyal yenilikçilik, bilişsel yenilikçilik ve fonksiyonel yenilikçilik boyutlarının sosyal risk bağımlı değişkenine etkisini tespit etmek için yapılan çoklu regresyon analizi sonucuna göre regresyon modelinin anlamlı olmadığı görülmektedir ( $F=1.613, p>.05)$. Tüketici yenilikçiliği boyutlarının sosyal riski boyutunu açıklama oranı $\left(\mathrm{R}^{2}\right), 006$ düzeyindedir. Fonksiyonel yenilikçilik boyutunun sosyal risk boyutu üzerinde etkisi var iken, hedonik, sosyal ve bilişsel yenilikçilik boyutlarının sosyal risk boyutu üzerinde etkisi olmadığı görülmektedir.

Çoklu doğrusal bağlantı sorununun olup olmadığını tespit etmek için tolerans ve VIF değerlerine bakılabilir. Tolerans değerinin .10'un üzerinde ve VIF değerinin de $10^{\prime}$ dan küçük veya eşit olması çoklu doğrusal bağlantı probleminin olmadığını göstermektedir (Pallant, 2016: 176). Tablo 14'te yer alan tolerans ve VIF değerlerine bakıldığında çoklu doğrusal bağlantı sorunun olmadığı görülse de tüketici yenilikçiliği boyutlarının sosyal risk üzerine etkisinin olmadığı görülmektedir. Bu durumda $\mathrm{H}_{2 \mathrm{~d}}$ hipotezi reddedilmiştir.

\section{SONUÇ VE TARTIŞMA}

Tüketici yenilikçiliği ile algılanan riskin negatif az derecede bir ilişkiye sahip olduğu görülmektedir. Ölçek boyutları arasındaki ilişki incelendiğinde hedonik, bilişsel ve fonksiyonel yenilikçilik boyutları ile algılanan risk boyutları arasında negatif bir ilişki var iken, sosyal yenilikçilik boyutu ile algılanan risk boyutlarının bir ilişkiye sahip olmadığı görülmektedir. Bu nedenle hedonik, bilişsel ve fonksiyonel yenilikçilik düzeyi arttıkça algılanan risk düzeyi azalmaktadır. Lee ve Huddleston (2006) ve Cowart vd., (2008) tüketici yenilikçiliği ile algılanan risk arasında negatif yönlü bir ilişki bulmuştur. Türkiye'de ise Özoğlu ve Bülbül (2013) üniversite öğrencileri üzerine yapılan araştırmada tüketici yenilikçiliği ile algılanan risk arasında negatif yönlü bir ilişki bulmuştur. Araştırmadan elde edilen sonucun önceki araştırmaları desteklediği görülmektedir.

Tüketici yenilikçiliğinin algılanan risk üzerine etkisini belirlemek amacıyla yapılan analiz sonuçlarına göre bilişsel yenilikçilik boyutunun toplam-zaman riski, fiziksel-performans riski, psikolojik-finansal risk boyutu ve sosyal risk boyutu üzerinde etkisi yok iken, hedonik, sosyal ve fonksiyonel yenilikçilik boyutlarının etkisi olduğu görülmektedir. Fonksiyonel yenilikçilik boyutunun sosyal risk boyutu üzerinde etkisi var iken, hedonik, sosyal ve bilişsel yenilikçilik boyutlarının sosyal risk boyutu üzerinde etkisi olmadı̆̆ı görülmektedir. Hirunyawipada ve Paswan (2006) yapmış oldukları çalışmada yeni ürünlerin belirsizlik özelliği taşıdığı ve tüketicilerin yeni ürünü satın alırken risk algıladığı, ancak bu durum yeni ürünün satın alınmasına etki etmediği sonucuna varmıştır. Çifci'nin (2012) yenilikçilik boyutlarının yeni teknolojik ürünlere yönelik tüketicinin tutumlarının etkisinin ne olduğunun araştırıldığ çalışmada ise hedonik yenilikçilik boyutunun tüketicinin tutumuna etkisi var iken, sosyal yenilikçilik boyutunun etkisinin olmadığı görülmektedir. Afzal'ın (2013) ve Suki ve Suki'nin (2007) yapmış oldukları çalışmalarda algılanan riskin online alışveriş yenilikçiliğine ilişkin tüketicilerin tutumunu olumlu yönde etkilediği sonucuna varmışlardır. Daha önceki yapılan çalışmalara bakıldığında bu araştırmanın sonuçları ile örtüştüğü 
görülmektedir. $\mathrm{Bu}$ doğrultuda kişilerin yeteneklerini geliştiren, zihnini çalıştıran, mantıksal olarak düşünmeye sevke eden ve bilgilerini artıracak yenilikleri benimsemeleri algıladıkları risk düzeyini azaltıcı veya artırıcı bir etkiye sahip değildir. Ayrıca daha fazla konfora, fonksiyonelliğe sahip, zaman tasarrufu sağlayan ve kullanışlı yeni bir ürünü satın almaktan çekinmeyen bir kişi arkadaşları arasında itibarının artacağını, arkadaşları tarafından gösteriş yaptığını ve akılsızca davranıldığı düşüncesini önemsememektedir.

Tüketici yenilikçiliği boyutlarının toplam-zaman riski üzerindeki göreli önem sırasına bakıldığında sırasıyla fonksiyonel yenilikçilik, sosyal yenilikçilik, hedonik yenilikçilik olduğu görülmektedir. Fonksiyonel yenilikçilik toplam-zaman riski üzerinde en fazla etkiye sahiptir. Bu nedenle işletmeler yeni bir ürün veya hizmet sunarken konfor, fayda ve zaman tasarrufu sağlayacak ürün veya hizmet sunmalıdır. Tüketici yenilikçiliği boyutlarının fiziksel-performans riski üzerindeki göreli önem sırasına bakıldığında ise sırasıyla hedonik yenilikçiliğin, sosyal yenilikçiliğin ve fonksiyonel yenilikçiliğin etki ettiği görülmektedir. Hedonik yenilikçilik fiziksel-performans riski üzerinde en fazla etkiye sahiptir. Bu nedenle işletmeler yeni bir ürün veya hizmet sunarken tüketicinin mutlu olmasını sağlayan, haz ve heyecan veren ürünlere yönelerek fiziksel ve performans riskini en aza indirebilirler. Tüketici yenilikçiliği boyutlarının psikolojik-finansal risk üzerindeki göreli önem sırasına bakıldığında da sırasıyla sosyal yenilikçiliğin, hedonik yenilikçiliğin, fonksiyonel yenilikçiliğin etki ettiği görülmektedir. Sosyal yenilikçilik psikolojik-finansal risk üzerinde en fazla etkiye sahiptir. Sosyal riske etki eden yenilikçilik boyutu ise fonksiyonel yenilikçiliktir. Bu nedenle işletmeler tüketicilerin çevresine karşı itibarını, saygınlığını artıran ve çevresine kendini gösterebileceği ürün veya hizmetler sunarak performans ve psikolojik risk algısını en aza indirebilirler. Fayda, konfor ve zaman tasarrufu sağlayan ürün veya hizmetlerin tüketiciler tarafından tercih edilmesi ise çevresi tarafından hoş karşılanacağını ve itibarını artıracağını göstermektedir.

Küreselleşmenin etkisiyle giderek artan rekabet koşulları bir konaklama işletmesini diğer konaklama işletmelerinden farklı kılan ve daha ön planda olmasını sağlayan yenilik kavramına önem verilmesi gerektiğini göstermektedir. Bir konaklama işletmesinin daha çok tüketici kazanmak adına yenilikler yapması ve bu yeniliklerin otel misafirleri tarafından benimsenmesi gerekmektedir. Otel misafirlerinin istek ve beklentilerindeki farklılıklar işletmeleri yeniliğe zorlamaktadır. Bu nedenle konaklama işletmeleri ürün veya hizmetlerini pazara sunarken tüketicinin istekleri ve beklentileri doğrultusunda hareket etmesi gerekmektedir.

Tüketici yenilikçiliği kavramı son zamanlarda önem kazanan bir kavramdır. Konu hakkında literatürde yeteri kadar araştırma yapılmamıştır. Bu nedenle bu araştırma literatüre katkı sağlayacaktır. Ayrıca bu araştırmanın daha önce araştırılmamış olması, gelecek araştırmalar için ışık tutacaktır. Kuşadası'nda 5 yıldızlı konaklama işletmeleri üzerine uygulanan bu araştırma, farklı bir destinasyonda, 3 veya 4 yıldızlı konaklama işletmeleri üzerine de uygulanabilir. Aynı zamanda konaklama işletmeleri dışında seyahat acentaları ve yiyecek-içecek işletmeleri gibi farklı alanlarda da uygulanabilir.

\section{KAYNAKLAR}

Afzal, S. (2013), "Factors Influencing Successful Brand Extension Into Related And Unrelated Product Categories", Asian Economic And Financial Review, 3(2), 216-226.

Akdoğan, M. Ş., ve Karaaslan, M. H. (2013). Tüketici Yenilikçiliği. Atatürk Üniversitesi İktisadi ve İdari Bilimler Dergisi, 27(2), 1-20.

Akturan, U. (2007). Satınalma Karar Sürecinde Markaya Yönelik Algılanan Riskin Algılanan Değer Üzerindeki Etkisi. Yayımlanmamış Doktora Tezi, İstanbul Üniversitesi, Sosyal Bilimler Ensitütüsü, İstanbul.

Ateşoğlu, İ., ve Türker, A. (2014). Tatil Yeri Seçiminde Ülke İmajının Turistin Risk Algısı Üzerine Etkisi. Uluslararası Alanya İsletme Fakültesi Dergisi, 6(2), 09-28.

Aydın İl Turizm Müdürlüğü. (2018). İşletme Belgeli $\quad$ Tesisler, http://www.aydinkulturturizm.gov.tr/Eklenti/61056,bakanlik-belgeli-tesisler---site-2018-12pdf.pdf?0 (Erişim tarihi: 28 Ağustos 2018).

Başar, E. E. (2012). Tüketici Yenilikçiliği ve Marka Değeri Algısının Marka Yayma Üzerindeki Etkileri. Yayımlanmamış Yüksek Lisans Tezi, Atatürk Üniversitesi Sosyal Bilimler Enstitüsü, Erzurum. 


\section{Baykal - A. Yazıcı Ayyıldız 12/1 (2020) 510-530}

Boksberger, P. E., Bieger, T., and Laesser, C. (2007). Multidimensional analysis of perceived risk in commercial air travel. Journal of Air Transport Management(13), 90-96.

Bülbül, H., ve Özoğlu, B. (2014). Tüketici Yenilikçiliği ve Algılanan Riskin Satın Alma Davranışına Etkisi. Erciyes Üniversitesi İktisadi ve İdari Bilimler Fakültesi Dergisi, (44), 43-58.

Carroll, M. S. (2009). Development of a Scale to Measure Perceived Risk in Collegiate Spectator Sport and Assess Its Impact on Sport Consumption Intentions. Doctoral Thesis, The University of Florida, Florida.

Chao, C. W., Reid, M., and Mavondo, F. (2013). Global Consumer Innovativeness and Consumer Electronic Product Adoption. Asia Pacific Journal of Marketing and Logistics, 25(4), 614-630.

Çifci, S. (2012). “Tüketicilerin Yeni Ürünlere Yönelik Adaptasyon Tutumları Üzerinde Tüketicilerin ve Firmaların Yenilikçilik Düzeylerinin Etkisi”. Dumlupınar Üniversitesi Sosyal Bilimler Dergisi, 34, 83-92.

Cohen, J. W. (1988). Statistical Power Analysis for the Behavioral Sciences (2nd edition). Hillsdale: Lawrence Erlbaum Associates.

Cowart, K. O., Fox, G. L., and Wilson, A. E. (2008). A Structural Look at Consumer Innovativeness and SelfCongruence in New Product Purchases. Psychology \& Marketing, 25(12), 1111-1130.

Daghfous, N., Petrof, J. V., and Pons, F. (1999). Values and Adoption of Innovations: A Cross-Cultural Study. Journal of Cunsumer Marketing, 16(4), 314-331.

Demireli, C. (2014). Tüketici Yenilikçiliği ve Gönüllü Yaşam Tarzı Arasındaki İlişkinin İncelenmesi. Yönetim ve Ekonomi Araştırmaları Dergisi(24), 320-337.

Deniz, A. (2012). Tüketici Yenilikçiliğinin Boyutları ve Yenilikçiliği Etkileyen Faktörler Arasındaki İlişkiler. Doktora Tezi, Atatürk Üniversitesi Sosyal Bilimler Enstitüsü, Erzurum.

Featherman, M. S., and Pavlou, P. A. (2003). Predicting e-services adoption: a perceived risk facets perspective. Int. J. Human-Computer Studies (59), 451-474.

Goldsmith, R. E., \& Hofacker, C. F. (1991). Measuring Consumer Innovativeness. Journal of the Academy of Marketing Science, 19(3), 209-221.

Goldsmith, R.E., Flynn, L.R. and Goldsmith, E.B. (2003), "Innovative consumers and market mavens", Journal of Marketing Theory and Practice, 11(4), pp. 54-65.

Hair, J. F., Black, W. C., Babin, B. J., and Anderson, R. E. (2014). Multivariate data analysis: A global perspective (7th Edition). Upper Saddle River, NJ: Pearson.

Handa, M. and Gupta, N. (2009), "Gender influence on the innovativeness of young urban Indian online shoppers", The Journal of Business Perspective, 13(2), pp. 25-32.

Haşıloğlu, S. B., Baran, T., ve Aydın, O. (2015). Pazarlama Araştırmalarındaki Potansiyel Probeleme Yönelik Bir Araştırma: Kolayda Örnekleme ve Sıklık İfadeli Ölçek Maddeleri. Pamukkale İşletme ve Bilişim Yönetimi Dergisi, 2(1), 19-28.

Hirschman, E. C. (1980). Innovativeness, Novelty Seeking, and Consumer Creativity. Journal of consumer Research, 283-295.

Hirunyawipada, T., Paswan, A. K. (2006), “Consumer Innovativeness and Perceived Risk: Implications For High Technology Product Adoption", Journal Of Consumer Marketing, 23(4), 182-198.

Joseph, M. L. (2007). Innovativeness In Nursing: A Phenomenological And Constructivist Study. Doctoral Thesis, Capella University, Minnesota.

Kambar, R. (2016). Tüketici Yenilikçiliği ve Ürün İlgileniminin Marka Sadakati Üzerindeki Etkisi. Yayımlanmamış Doktora Tezi, Kocaeli Üniversitesi Sosyal Bilimler Enstitüsü, Kocaeli.

Karabulut, A. N. (2013). Tüketicilerin Algılanan Risk Değişkeni Karşısında İnternetten Alışveriş Yapma Eğilimlerinin Ölçülmesi: Beklenen Fayda Teorisine Karşı Beklenti Teorisi. Yaşar Üniversitesi Dergisi, $8(32), 5515-5536$. 
M. Baykal - A. Yazıcı Ayyıldız 12/1 (2020) 510-530

Karamustafa, K., ve Erbaş, E. (2011). Satın Alma Karar Sürecinde Algılanan Risk: Paket Turlara Yönelik Bir Araştırma. Tüketici ve Tüketim Araştırmaları Dergisi, 3(1), 103-144.

Klink, R.R. and Athaide, G.A. (2010), "Consumer innovativeness and the use of new versus extended brand names for new products", Journal of Product Innovation Management, 27(1), 23-32.

Koç, F., Giray, C., Girişken, Y. (2017). Tüketici Yenilikçiliği ve Davranışsal Niyetler Arasındaki İlişkide Sisteme Güven ve Algılanan Riskin Düzenleyici Etkisi: Instagram Dükkân Uygulamasına Yönelik Bir Araştırma. Beykoz Akademi Dergisi, 5 (2), 232-252.

Köker, N. E., ve Maden, D. (2017). Tüketici Yenilikçinin, Öz Saygı ve Sosyal Kimlik Boyutları Temelinde İncelenmesi: İtalya ve Türkiye Üzerine Bir Araştırma. Hitit Üniversitesi Sosyal Bilimler Enstitüsü Dergisi, 10(2), 835-854.

Köse, B. (2012). Tüketici Yenilikçiliği ve Yeniliklerin Benimsenmesi: Bir Yenilik Olarak Mobil İnternet. Yayımlanmamış Doktora Tezi, Afyon Kocatepe Üniversitesi Sosyal Bilimler Enstitüsü, Ayfon .

Küpeli, T. Ş. (2014). Algılanan Risk ve Algılanan Değer Arasındaki İlişkilerin Otel Müşterileri Üzerinde İncelenmesi. Yayımlanmamış Yüksek Lisans Tezi, Hacettepe Üniversitesi Sosyal Bilimler Enstitüsü, Ankara.

Lee, H. J., and Huddleston, P. (2006). Effects of e-tailer and product type on risk handling in online shopping. Journal of Marketing Channels, 13(3), 5-28.

Leicht, T., Chtourou, A., and Youssef, K. B. (2018). Consumer Innovativeness and Intentioned Autonomous Car Adoption. Journal of High Technology Management Research(29), 1-11.

Menidjel, C., Benhabib, A., and Bilgihan, A. (2017). Examining The Moderating Role of Personality Traits in The Relationship Between Brand Trust and Brand Loyalty. Journal of Product and Brand Management, 26(6), 631-649.

Midgley, D. F., and Dowling, G. R. (1978). Innovativeness: The Concept and Its Measurement. Journal of Consumer Research, 4(4), 229-243.

Mitchell, V.-W. (1998). A role for consumer risk perceptions in grocery retailing. British Food Journal, 100(4), 171-183.

Özçiftci, V. (2015). Tüketici Yenilikçiliğinin ve Moda Yenilikçiliği İlişkisinini İncelenmesi. Social Sciences (NWSASOS), 10(4), 135-148.

Özoğlu, B., ve Bülbül, H. (2013). Güdülenmiş Tüketici Yenilikçiliği ve Algılanan Risk Ölçeklerinin Geçerlilik ve Güvenilirlik Çalışması. Uluslararası Alanya İşletme Fakültesi Dergisi, 5(3), 131-139.

Pallant, J. (2016). Spss Kullanma Kılavuzu Spss İle Adım Adım Veri Analizi. (Çev. Balcı, S. ve Ahi, B.) Ankara: Anı Yayıncilık (Eserin orijinali 2015'te yayımlandı).

Roehrich, G. (2004). Consumer Innovativeness Concepts and Measurements. Journal of Business Research(57), 671-677.

Rogers, E. M. (1983). Diffusion of Innovation (Üçüncü Baskı). New York: The Free Press.

Rogers, E.M. and Shoemaker, F.F. (1971), Communication of Innovations, The Free Press, New York, NY

Roselius, T. (1971). Consumer Rankings of Risk Reduction Methods. Journal of Marketing(35), 56-61.

Ross, I. (1975). Perceived Risk and Consumer Behavior: a Critical Review. Advances in Consumer Research, 2, $1-20$.

Stone, R. N., and Grønhaug, K. (1993). Perceived Risk: Further Considerations for the Marketing Discipline. European Journal of Marketing, 27(3), 39-50.

Şencan, H. (2005). Sosyal ve Davranışsal Ölçümlerde Güvenilirlik ve Geçerlilik. Ankara: Seçkin Yayıncılık.

Suki, Norbayah. M. and Suki, Norazah. M., (2007), “Online Buying Innovativeness: Effects of Perceived Value, Perceived Risk and Perceived Enjoyment", International Journal of Business nnd Society; 8(2), Pp. 81-93. 
M. Baykal - A. Yazıcı Ayyıldız 12/1 (2020) 510-530

Tabachnik, B. G., and Fidell, L. S. (2013). Using multivariate statistics. Allyn \& Bacon Pearson Education.

Tellis, G. J., Yin, E., and Bell, S. (2009). Global Cunsomer Innovativeness: Cross-Country Differences and Demografic Commonalities. Journal of International Marketing, 17(2), 1-22.

Temeloğlu, E. (2016). Turistlerin Tatil Satın Alma Sürecinde Algıladıkları Risklerin Demografik Özelliklere Göre İncelenmesi. Pamukkale Üniversitesi Sosyal Bilimler Enstitüsü Dergisi(25), 99-119.

Vandecasteele, B., and Geuens, M. (2010). Motivated Consumer Innovativeness: Concept, measurement, and validation. International Journal of Research in Marketing, 27, 308-318.

Venkatraman, M. P. (1991). The Impact of Innovativeness and Innovation Type on Adoption. Journal of Retailing, 67(1), 51-67.

Wooyang, K., Di Benedetto, C. A., and Lancioni, R. A. (2011). The Effects of Country and Gender Differences on Consumer Innovativeness and Decision Processes in a Highly Globalized High-tech Product Market. Asia Pacific Journal of Marketing and Logistics, 23(5), 714-744.

Yaşlığlu, M. M. (2017). Sosyal Bilimlerde Faktör Analizi ve Geçerlilik: Keşfedici ve Doğrulayıcı Faktör Analizlerinin Kullanılması. İstanbul Üniversitesi İşletme Fakültesi Dergisi, 46(Özel sayı), 74-85. 